\title{
Optimasi Perbaikan Faktor Daya Dengan Pemasangan DC Reaktor Akan Mereduksi Harmonisa Di Inverter Motor Pendingin Air Industri
}

\author{
Soetjipto Soewono'; Jakariya² \\ ${ }^{1}$ Jurusan Teknik Elektro, Sekolah Tinggi Teknik PLN, Jakarta \\ ${ }^{1}$ soetjipto@sttpln.ac.id \\ ${ }^{2}$ riya.jaka@yahoo.co.id
}

\begin{abstract}
Three phase induction motor is widely used in the manufacturing industry because it has many advantages including easy maintenance, efficient use in various fields, durability and easy construction. This is behind the massive use of motorcycles. but the 3 phase induction motor also has disadvantages such as high starting currents and difficult to regulate speed. After emerging innovations regarding inverters as induction motor starters, the application of the device expanded because of its principle which regulates the number of motor frequencies slowly so as to make the 3-phase induction motor more efficient.

The use of an inverter is indeed a solution to the problem of starting a 3-phase induction motor and regulating the motor speed, but behind the advantages there are disadvantages that the inverter produces a low power factor when operating the motor. The highest power factor when the inverter is working is 0.748 , the lowest value is 0.478 and the average is 0.634 . Based on this, it is necessary to optimize the improvement of the power factor to restore the condition of the motor to a standard power factor rating of 0.85 .

This research discusses the optimization of the improvement of the power factor by installing the $D C$ reactor on the inverter unit and the results of an increase in the value of the highest power factor of 0.942, for the lowest value of 0.908 and an average of 0.927 . the value of harmonics in the THD I1 $(R)$ phase for the highest value of $184,230 \%$, then the lowest value of $83,764 \%$ and for an average value of $119,329 \%$.
\end{abstract}

Keywords: Motor, Inverter, Power Factor

\begin{abstract}
ABSTRAK
Motor induksi 3 fasa banyak digunakan dalam dunia industri manufaktur karena memiliki banyak keunggulan diantaranya seperti mudah perawatan, efisiensi penggunaan diberbagai bidang, awet dan kontruksinya mudah. Hal tersebut melatarbelakangi masifnya penggunaan motor. namun motor induksi 3 fase juga memiliki kelemahan seperti arus start yang tinggi dan kecepatannya sulit diatur. Setelah muncul inovasi mengenai inverter sebagai starter motor induksi aplikasi alat tersebut meluas karena prinsipnya yang mengatur jumlah frekuensi motor secara perlahan sehingga menjadikan motor induksi 3 fase menjadi lebih efisien.

Penggunaan inverter memang menjadi solusi terhadap masalah starting motor induksi 3 fase dan pengaturan kecepatan motor namun dibalik kelebihannya tersebut terdapat kelemahan yaitu inverter menghasilkan faktor daya yang rendah saat mengoperasikan motor. Nilai faktor daya saat inverter bekerja tertinggi sebesar 0.748 , untuk nilai terendah sebesar 0.478 dan rata-rata sebesar 0.634. berdasarkan hal tersebut maka perlu dilakukan optimasi perbaikan faktor daya untuk mengembalikan kondisi motor ke rating faktor daya standar sebesar 0.85 .
\end{abstract}


Dalam penelitian ini membahas optimasi perbaikan faktor daya dengan pemasangan DC reaktor pada unit inverter dan hasil terjadi kenaikan nilai faktor daya tertinggi sebesar 0.942, untuk nilai terendah sebesar 0.908 dan rata-rata sebesar 0.927. nilai harmonisa pada fasa THD I1 (R) untuk nilai tertinggi sebesar $184.230 \%$, kemudian nilai terendah sebesar $83.764 \%$ dan untuk nilai rata-rata sebesar $119.329 \%$.

Kata kunci: Motor, Inverter, Faktor Daya 


\section{PENDAHULUAN}

Motor induksi 3 fase banyak digunakan sebagai penggerak utama pada industri manufaktur. Motor ini bisa digunakan sebagai penggerak untuk menggerakan mesin atau sebagai motor penunjang kegiatan produksi seperti motor pendingin air untuk proses pendinginan. Motor induksi mempunyai beberapa kelebihan antara lain, bentuk yang sederhana, konstruksi cukup kuat, harga murah dan dapat diandalkan. Motor pendingin tersebut bekerja 24 jam sehari sehingga motor tersebut keberadaannya sangat penting dalam aktivitas produksi. Permasalahan yang muncul dalam pengoperasian motor pendingin tersebut yaitu faktor daya rendah, kemudian adanya harmonisa berimbas pada efisiensi dan kinerja motor yang kurang optimal. seperti diketahui faktor daya merupakan cosinus dari beda sudut fasa antara arus dan tegangan semakin mendekati 1 maka nilai faktor daya akan semakin baik. Kemudian untuk mencari nilai faktor daya dapat dilakukan dengan membagi daya aktif $(P)$ dengan daya semu $(S)$.

Faktor daya yang rendah disebabkan oleh penggunaan beban induktif dan pemasangan peralatan inverter sebagai starter motor induksi 3 fase tersebut. Akibat faktor daya rendah maka arus yang diserap motor lebih tinggi, hal ini bertambah parah karena harmonisa muncul dalam pengoperasian inverter motor sehingga rating arus aktual berada diatas nilai standar pabrikan.

Harmonisa adalah gangguan yang terjadi pada sistem distribusi tenaga listrik akibat terjadinya distorsi gelombang arus dan tegangan. Pada dasarnya, harmonisa adalah gejala pembentukan gelombang-gelombang dengan frekuensi berbeda yang merupakan perkalian bilangan bulat dengan frekuensi dasarnya. Efek yang dihasilkan oleh gejala harmonisa seperti umur peralatan menjadi tidak awet, cepat panas dan kawat netral akan teraliri arus.

Dalam penelitian ini akan membahas optimasi perbaikan faktor daya dengan pemasangan dc reaktor yang akan mereduksi harmonisa di inverter motor pendingin air industri.

\section{METODE/PERANCANGAN PENELITIAN}

\subsection{Jenis Penelitian}

Dalam penelitian ini menggunakan metode kualitatif dimana data yang didapatkan di lapangan akan diolah dan digunakan untuk dianalisa hingga mendapatkan kesimpulan akhir bagaimana optimasi perbaikan faktor daya dengan pemasangan DC reaktor mampu mereduksi harmonisa yang diakibatkan penggunaan inverter motor.

Pengambilan sampel data awal dilakukan langsung pada 2 buah unit inverter motor dengan spesifikasi sama dan merk yang sama yang berbeda adalah pemasangan unit dc reaktor pada salah satu inverter. Pengambilan data ini akan dilakukan menggunakan alat power analyzer PQ-BOX 100 sehingga nilai faktor daya, harmonisa, arus dan tegangan bisa terekam dengan baik.

Adapun dokumen yang diambil berupa:

1. Teori Faktor Daya

2. Teori Harmonisa

2. Teori Mesin Listrik AC

3. Single Line Diagram Panel MCC Chiller

4. Report Power Metering Desember 2017

5. Jurnal IImiah tentang faktor daya dan harmonisa: 


\subsection{Sumber Data}

Metode pengumpulan data dalam penelitian ini dilakukan pengukuran menggunakan power analyser yang terhubung pada beban output inverter ke motor, kemudian data yang ditampilkan akan disusun menggunakan software winPQ mobil. setelah itu dilakukan analisa secara menyeluruh untuk mendapatkan grafik yang akan ditampilkan pada pembahasan.

Pengambilan sampel data dilakukan langsung pada unit inverter motor. Pengambilan data ini akan dilakukan menggunakan alat power analyser PQ-BOX 100 sehingga nilai faktor daya, harmonisa, arus dan tegangan bisa terekam dengan baik.

Power Analyser PQ BOX 100 merupakan salah satu jenis alat ukur yang digunakan untuk menganalisa gejala harmonisa yang ada pada sistem kelistrikan, alat ini digunakan dalam penelitian untuk mendapatkan data yang akurat seperti tegangan, arus, flicker, harmonik, interharmonik, frekuensi, event recording dan parameter kelistrikan lainnyat ini.

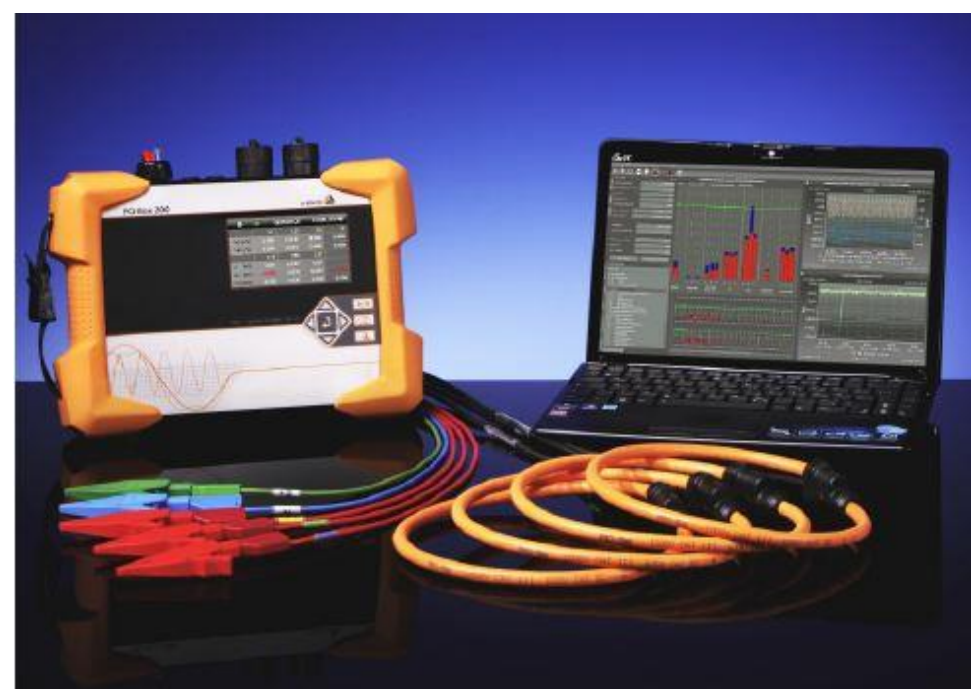

Gambar 1. Power Quality Analyser

Pengukuran menggunakan power quality analyser PQ-BOX 100 dilakukan tanggal 21 november 2018 pukul 00:00 sampai 23 november 2018 pukul 00:00 pada inverter motor pendingin air dan pengukuran ini telah mendapatkan nilai harmonisa tegangan dan harmonisa arus yang kemudian disusun menggunakan grafik

\subsection{Teknik Analisa Data}

Langkah I:

Dalam melakukan analisa optimasi perbaikan faktor daya dengan pemasangan DC reaktor pada inverter motor pendingin air industri menggunakan data awal yang berasal dari power metering, data ini merekam nilai faktor daya setiap 15 menit sekali, dari data awal ini akan dibandingkan dengan pengukuran menggunakan power analyser yang akan dipasang langsung pada inverter motor dan akan dibandingkan antara data keduanya tersebut. 


\section{Langkah II:}

Melakukan analisa kebutuhan untuk spesifikasi DC reaktor yang akan dipasang dan lakukan pemasangan DC reaktor dengan standar pemasangan pabrikan.

\section{Langkah III:}

Melakukan analisa terhadap faktor daya yang rendah pada inverter motor. Analisa ini meliputi bagaimana faktor daya mempengaruhi nilai tegangan dan arus baik secara langsung ataupun tidak langsung.

\section{Langkah IV:}

Melakukan pemasangan alat power analyser untuk merekam data secara real time dalam satuan detik agar tingkat keakuratan dari nilai data yang didapat bisa dipertanggung jawabkan.

\section{Langkah V:}

Lakukan power analysis secara keseluruhan berdasarkan data dari hasil pengukuran power metering dan power analyser. Setelah mendapatkan data lakukan pembahasan secara menyeluruh terhadap fakta \& data yang diperoleh.

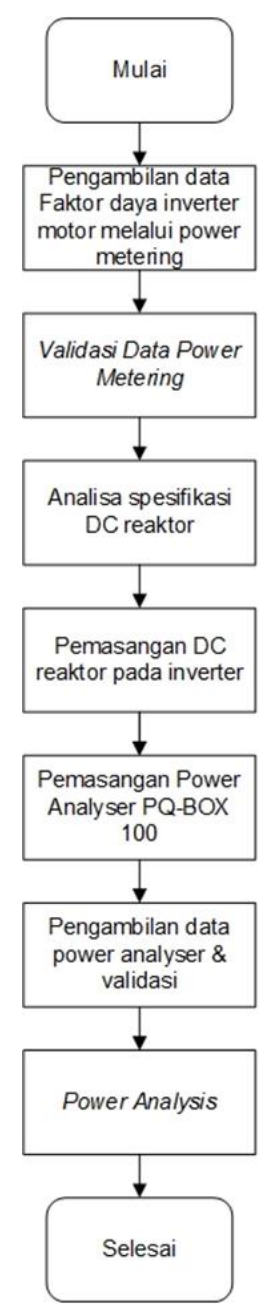

Gambar 2. Flowchart Penelitian 


\section{HASIL DAN PEMBAHASAN}

\subsection{Faktor Daya}

Pada tanggal 8 desember 2017 telah dilakukan pengambilan data dari data logger pada alat power metering panasonic dengan interval 15 menit, hasilnya adalah faktor daya yang terjadi pada sub panel motor pendingin air cukup rendah dimana dalam report tersebut nilai faktor daya paling rendah tercatat sebesar 0.39 , paling tinggi 0.85 dan nilai rata-rata secara keseluruhan adalah 0.69 selama periode pengukuran.

Tabel 1. Data awal power metering

\begin{tabular}{|c|c|c|c|c|c|c|c|c|c|}
\hline $08 / 12 / 2017$ & $\begin{array}{c}\text { MCC- } \\
\text { CHILLER } \\
\text { kWh }\end{array}$ & $\begin{array}{c}\text { MCC- } \\
\text { CHILLER V } \\
1-2\end{array}$ & $\begin{array}{c}\text { MCC- } \\
\text { CHILLER V } \\
2-3\end{array}$ & $\begin{array}{c}\text { MCC- } \\
\text { CHILLER V } \\
3-1\end{array}$ & $\begin{array}{c}\text { MCC- } \\
\text { CHILLER I } \\
1\end{array}$ & $\begin{array}{c}\text { MCC- } \\
\text { CHILLER I } \\
2\end{array}$ & $\begin{array}{c}\text { MCC- } \\
\text { CHILLER I } \\
3\end{array}$ & $\begin{array}{c}\text { MCC- } \\
\text { CHILLER PF }\end{array}$ & $\begin{array}{c}\text { MCC- } \\
\text { CHILLER F }\end{array}$ \\
\hline $0: 00: 00$ & 673132,82 & 403 & 403,7 & 402,1 & 111,05 & 114,87 & 106,68 & 0,77 & 50,1 \\
\hline $0: 15: 00$ & 673146,84 & 399 & 399,4 & 397,4 & 105,56 & 108,93 & 99,95 & 0,75 & 49,8 \\
\hline $0: 30: 00$ & 673156,36 & 397,9 & 398,4 & 396,2 & 102,09 & 106,28 & 96,15 & 0,77 & 50,1 \\
\hline $0: 45: 00$ & 673169,61 & 397,3 & 397,8 & 395,6 & 100,5 & 104,98 & 95,71 & 0,75 & 50 \\
\hline $1: 00: 00$ & 673179,43 & 396,7 & 397,6 & 395,3 & 87,19 & 92,05 & 82,47 & 0,72 & 50 \\
\hline 1:15:00 & 673193,59 & 396,1 & 396,4 & 394,3 & 107,14 & 111,67 & 100,21 & 0,77 & 49,7 \\
\hline Average & 673711,72 & 397,97 & 398,35 & 396,36 & 93,69 & 96,91 & 88,78 & 0,09 & 49,95 \\
\hline Max. value & 674278,6 & 404,6 & 404,7 & 403,1 & 140,05 & 142,84 & 131,26 & 0,85 & 50,2 \\
\hline Min. value & 673132,82 & 391,6 & 391,9 & 390,3 & 0,35 & 0,53 & 0,5 & 0,39 & 49,7 \\
\hline
\end{tabular}
berikut.

Hasil pengukuran faktor daya yang telah dilakukan mendapatkan data sebagai

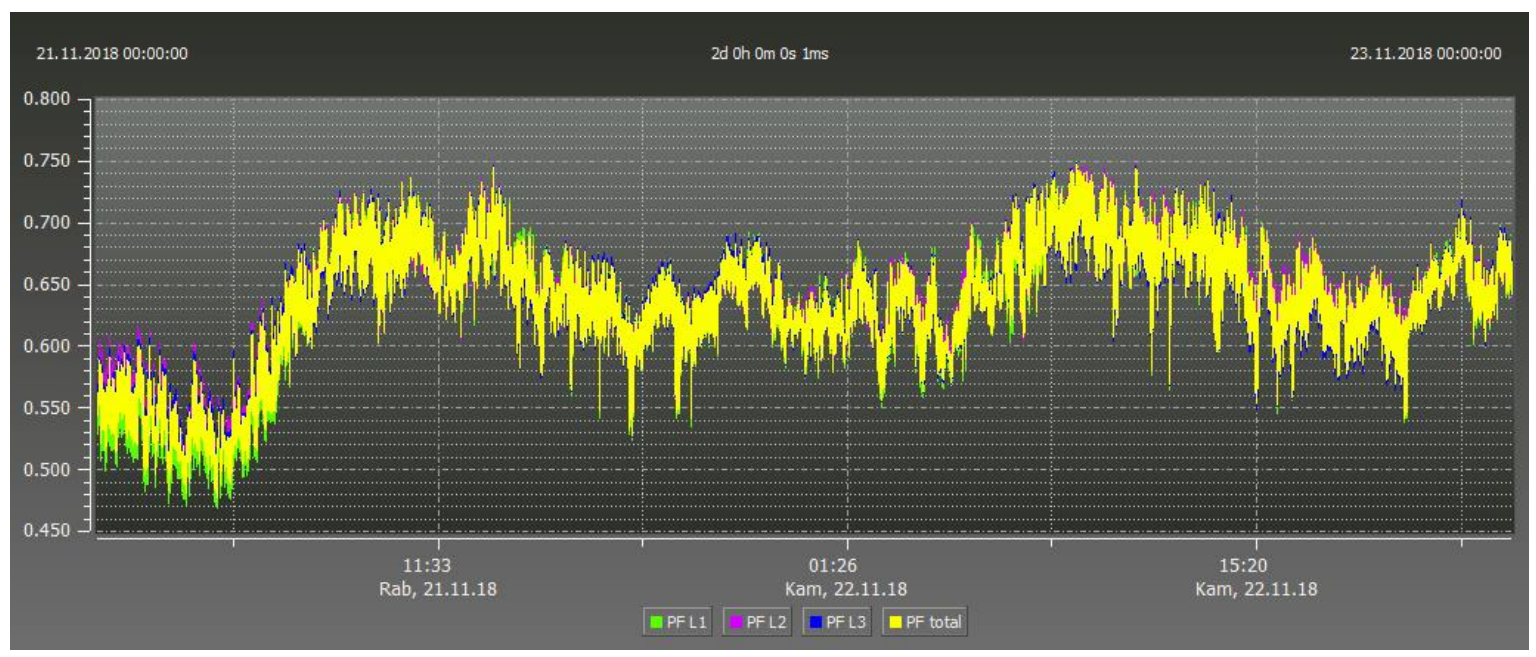

Gambar 3. Faktor Daya Sebelum Optimasi

Gambar 3 merupakan faktor daya total tiap fasa L1 (R), L2 (S), L3 (T). Dalam gambar tersebut dijelaskan bahwa nilai faktor daya tertinggi sebesar 0.748 , untuk nilai terendah sebesar 0.478 dan rata-rata sebesar 0.634 . 


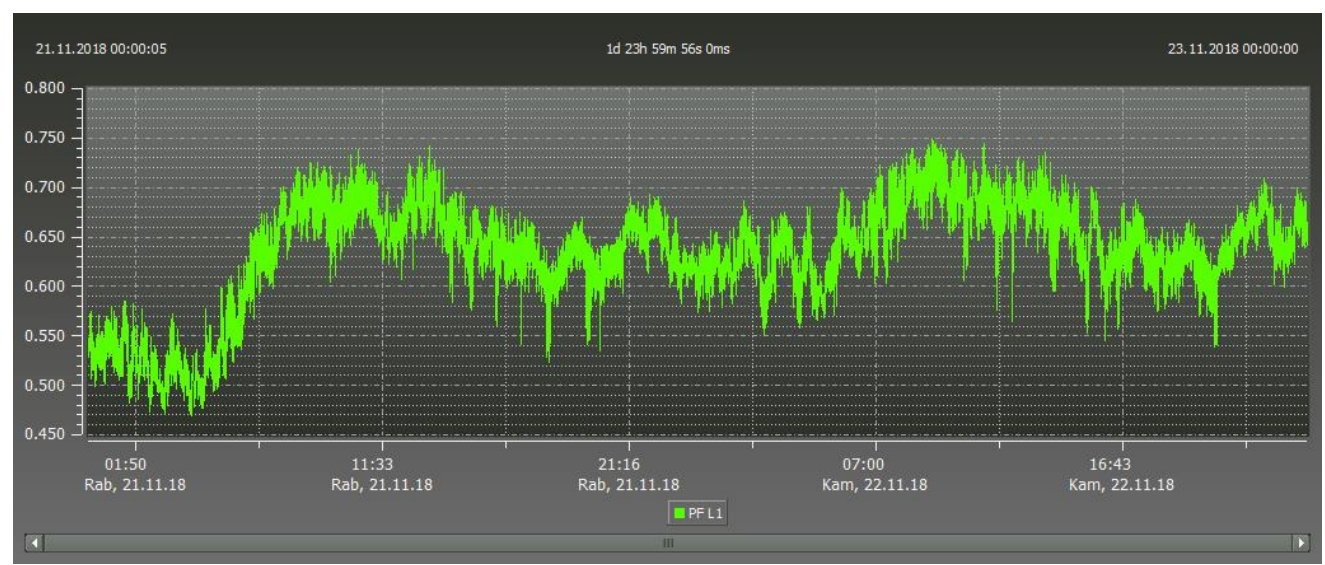

Gambar 4. Faktor Daya L1 (R)

Pada gambar 4 merupakan grafik faktor daya fasa $L 1(R)$ dalam grafik tersebut menjelaskan bahwa nilai faktor daya tertinggi sebesar 0.750. untuk faktor daya terendah sebesar 0.469 dan rata-rata sebesar 0.634 . Kemudian untuk faktor daya fasa L2 (S) grafik yang didapat seperti gambar berikut.

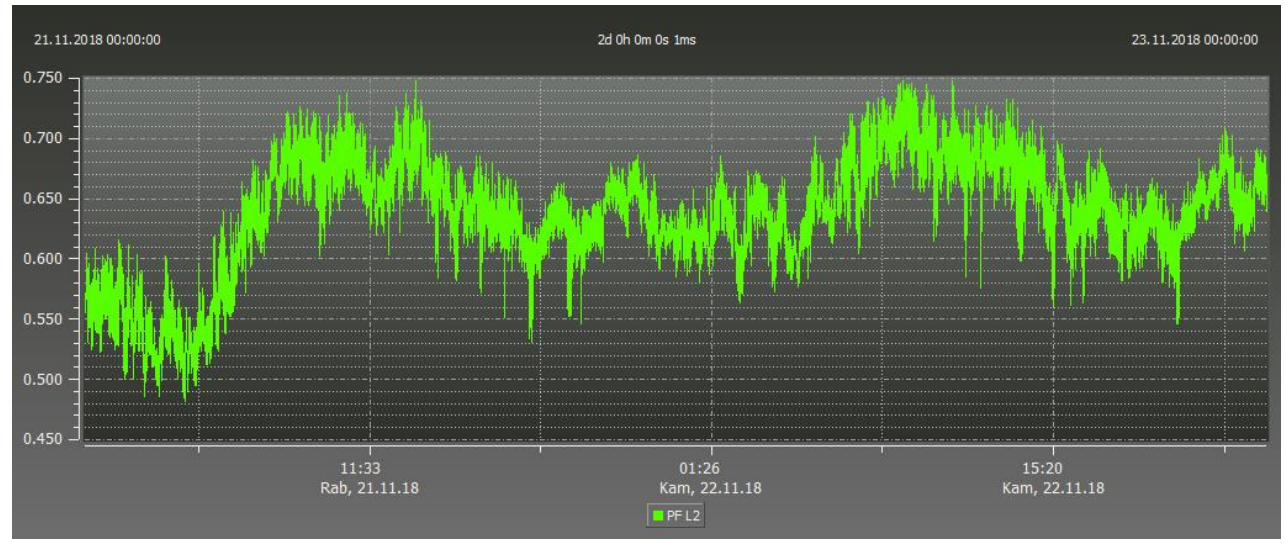

Gambar 5. Faktor Daya L2 (S)

Pada gambar 5. merupakan grafik faktor daya fasa L2 (S) dalam grafik tersebut menjelaskan bahwa nilai faktor daya tertinggi sebesar 0.748.untuk faktor daya terendah sebesar 0.481 dan rata-rata sebesar 0.637 . Kemudian untuk faktor daya fasa L3 (T) grafik yang didapat seperti gambar berikut.

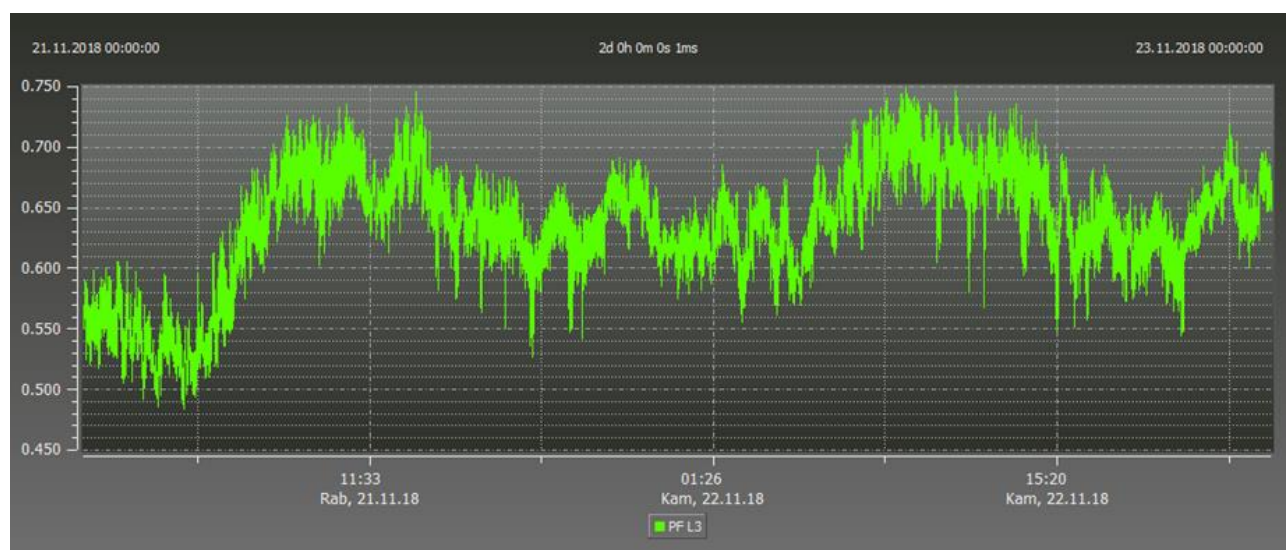

Gambar 6. Faktor Daya L3 (T) 
Pada gambar 6. merupakan grafik faktor daya fasa L3 (T) dalam grafik tersebut menjelaskan bahwa nilai faktor daya tertinggi sebesar 0.749. untuk faktor daya terendah sebesar 0.484 dan rata-rata sebesar 0.635 .

\subsection{Tegangan} berikut.

Hasil pengukuran tegangan yang telah dilakukan mendapatkan data sebagai

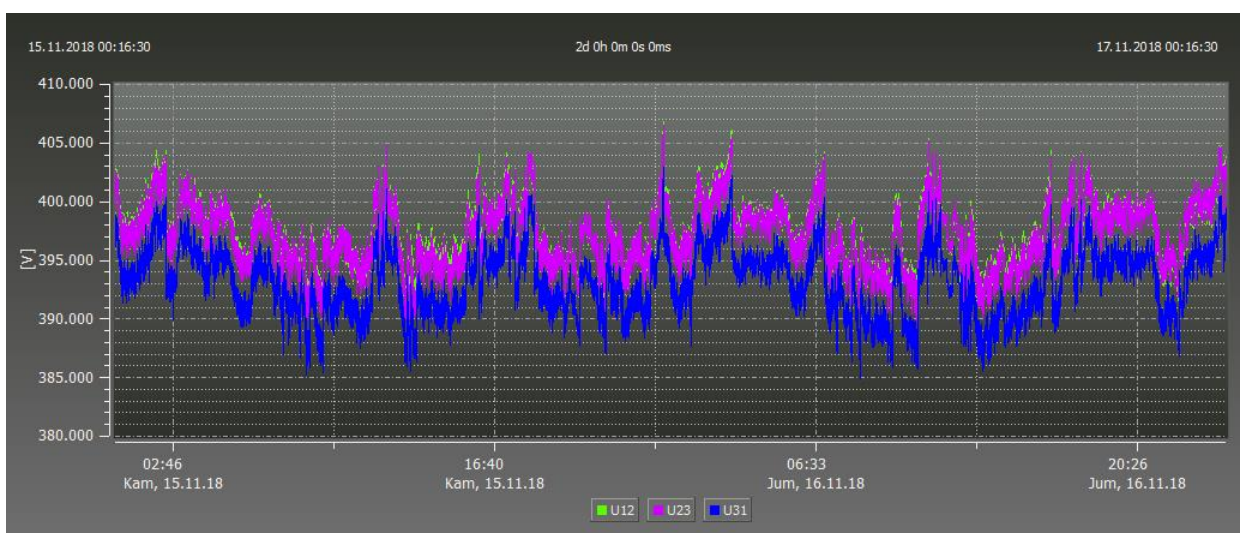

Gambar 7. Grafik Tegangan L1, L2, L3 (RST)

Gambar 7 menjelaskan grafik tegangan pada tiap fasa $L 1(R), L 2(S)$, \& $L 3(T)$ dimana dalam grafik tersebut dijelaskan bahwa nilai tegangan pada fasa L12 (RS) untuk nilai tertinggi sebesar $407.139 \mathrm{~V}$, kemudian nilai terendah sebesar $389.187 \mathrm{~V}$ dan untuk ratarata sebesar $397.962 \mathrm{~V}$. Lalu nilai tegangan pada fasa L23 (ST) untuk nilai tertinggi sebesar $406.858 \mathrm{~V}$, kemudian nilai terendah sebesar $389.252 \mathrm{~V}$ dan untuk rata-rata sebesar $397.958 \mathrm{~V}$. terakhir pada fasa L31 (TR) nilai tertinggi sebesar $402.981 \mathrm{~V}$, kemudian nilai terendah sebesar $385.210 \mathrm{~V}$ dan untuk nilai rata-rata sebesar $393.796 \mathrm{~V}$.

\subsection{Arus}

Hasil pengukuran arus yang telah dilakukan mendapatkan data sebagai berikut.

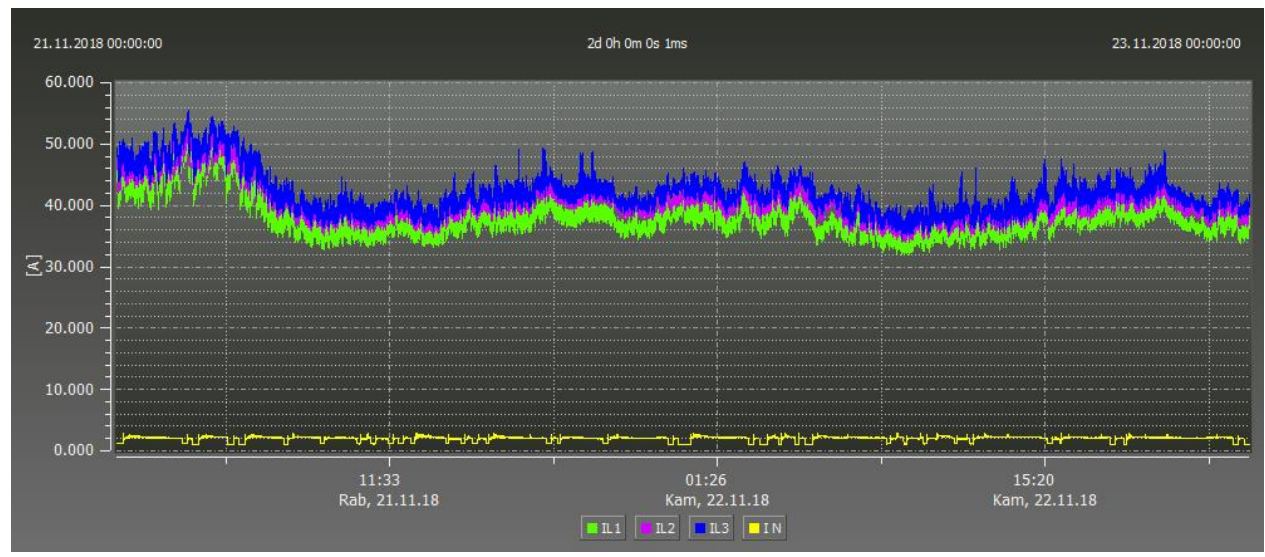

Gambar 8. Grafik Arus L1, L2, L3 (RST)

Gambar 8 menjelaskan grafik arus pada tiap fasa IL1(R), IL2(S), \& IL3(T) dimana dalam grafik tersebut dijelaskan bahwa nilai arus pada fasa IL1 $(R)$ untuk nilai tertinggi sebesar $52.388 \mathrm{~A}$, kemudian nilai terendah sebesar $31.857 \mathrm{~A}$ dan untuk nilai rata-rata 
sebesar 38.117 A. Lalu nilai arus pada fasa IL2 (S) untuk nilai tertinggi sebesar $52.725 \mathrm{~A}$, kemudian nilai terendah sebesar $33.908 \mathrm{~A}$ dan untuk rata-rata sebesar $40.628 \mathrm{~A}$. pada fasa IL3 (T) nilai tertinggi sebesar 55.453 A, kemudian nilai terendah sebesar $34.544 \mathrm{~A}$ dan untuk nilai rata-rata sebesar $41.963 \mathrm{~A}$. terakhir pada fasa IN nilai tertinggi sebesar $2.931 \mathrm{~A}$ kemudian nilai terendah $0.957 \mathrm{~A}$ dan untuk nilai rata-rata $1.990 \mathrm{~A}$.

\subsection{Daya Aktif}

Hasil pengukuran daya aktif yang telah dilakukan mendapatkan data sebagai berikut.

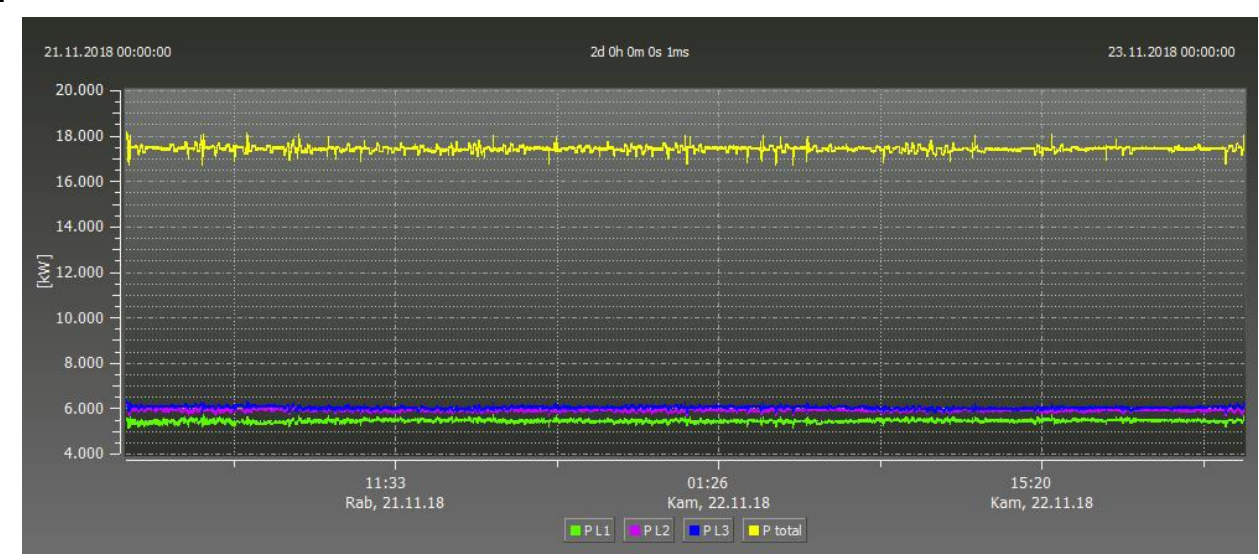

Gambar 9. Grafik Daya Aktif

Gambar 9. menjelaskan grafik daya aktif pada tiap fasa PL1(R), PL2(S), \& PL3(T) dimana dalam grafik tersebut dijelaskan bahwa nilai daya aktif pada fasa PL1(R) untuk nilai tertinggi sebesar $5.740 \mathrm{KW}$, kemudian nilai terendah sebesar $5.124 \mathrm{KW}$ dan untuk nilai rata-rata sebesar $5.463 \mathrm{KW}$. Lalu nilai daya aktif pada fasa PL2(S) untuk nilai tertinggi sebesar $6.284 \mathrm{KW}$, kemudian nilai terendah sebesar $5.668 \mathrm{KW}$ dan untuk ratarata sebesar $5.993 \mathrm{KW}$. selanjutnya pada fasa PL3(T) nilai tertinggi sebesar $6.372 \mathrm{KW}$, kemudian nilai terendah sebesar $5.578 \mathrm{KW}$ dan untuk nilai rata-rata sebesar $6.048 \mathrm{KW}$. Sehingga daya aktif $(P)$ total yang diserap motor untuk nilai tertinggi $18.181 \mathrm{KW}$, kemudian nilai terendah $16.703 \mathrm{KW}$ dan untuk nilai rata-rata sebesar $17.444 \mathrm{KW}$.

\subsection{Daya Reaktif} berikut.

Hasil pengukuran daya reaktif yang telah dilakukan mendapatkan data sebagai

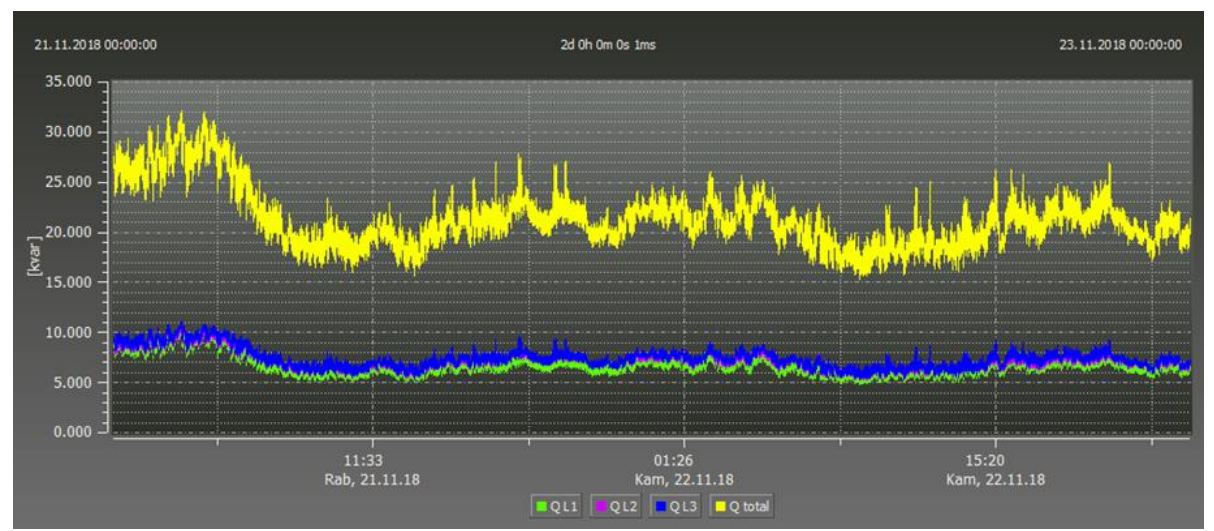

Gambar 10. Grafik Daya Reaktif 
Gambar 10 menjelaskan grafik daya reaktif pada tiap fasa QL1(R), QL2(S), \& QL3(T) dimana dalam grafik tersebut dijelaskan bahwa nilai daya reaktif pada fasa QL1(R) untuk nilai tertinggi sebesar $10.542 \mathrm{KVar}$, kemudian nilai terendah sebesar 4.828 $\mathrm{KVar}$ dan untuk nilai rata-rata sebesar $6.721 \mathrm{KVar}$. Lalu nilai daya reaktif pada fasa QL2(S) untuk nilai tertinggi sebesar $10.633 \mathrm{KVar}$, kemudian nilai terendah sebesar 5.204 KVar dan untuk rata-rata sebesar 7.229 KVar. Selanjutnya pada fasa QL3(T) nilai tertinggi sebesar $11.089 \mathrm{KVar}$, kemudian nilai terendah sebesar $5.244 \mathrm{KVar}$ dan untuk nilai ratarata sebesar $7.415 \mathrm{KVar}$. Sehingga daya reaktif $(\mathrm{Q})$ total yang diserap motor untuk nilai tertinggi $32.166 \mathrm{KVar}$, kemudian nilai terendah $15.320 \mathrm{KVar}$ dan untuk nilai rata-rata sebesar 21.409 Kvar.

\subsection{Daya Semu} berikut

Hasil Pengukuran daya semu yang telah dilakukan mendapatkan data sebagai

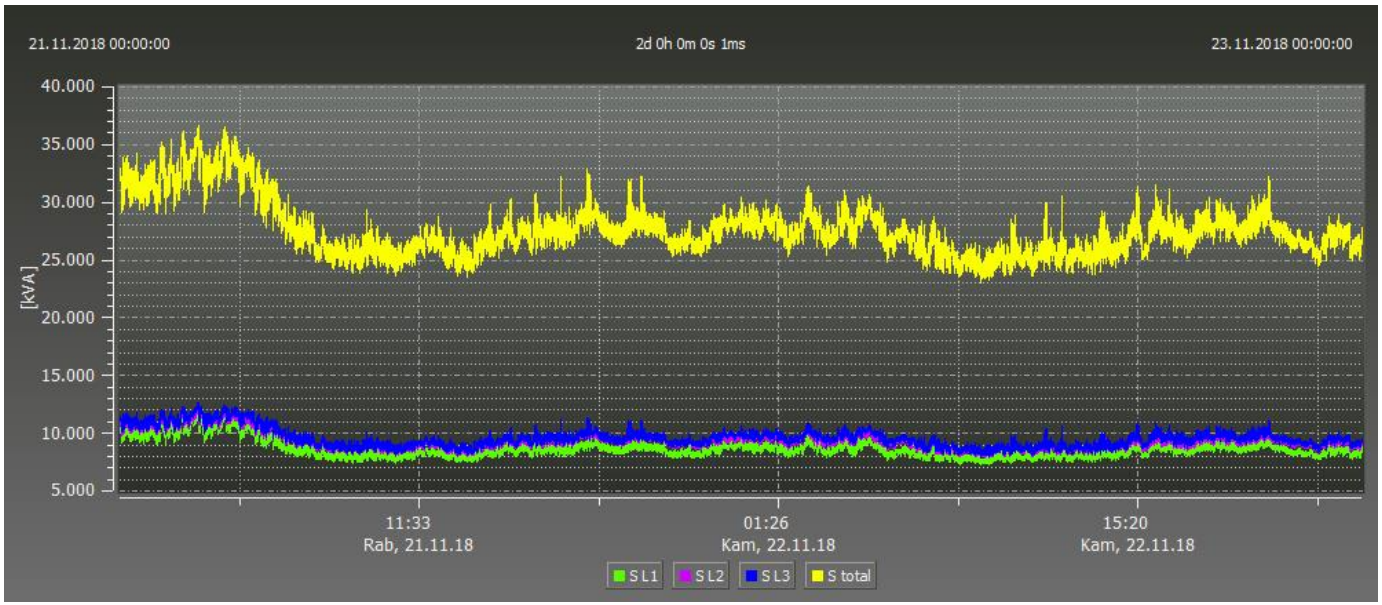

Gambar 10. Grafik Daya Semu

Gambar 10 menjelaskan grafik daya semu pada tiap fasa SL1(R), SL2(S), \& SL3(T) dimana dalam grafik tersebut dijelaskan bahwa nilai daya semu pada fasa SL1(R) untuk nilai tertinggi sebesar $11.938 \mathrm{KVA}$, kemudian nilai terendah sebesar 7.297 KVA dan untuk nilai rata-rata sebesar $8.682 \mathrm{KVA}$. Lalu nilai daya semu pada fasa PL2(S) untuk nilai tertinggi sebesar $12.168 \mathrm{KVA}$, kemudian nilai terendah sebesar $7.842 \mathrm{KVA}$ dan untuk rata-rata sebesar 9.371 KVA. Selanjutnya pada fasa PL3(T) nilai tertinggi sebesar 12.691 KVA, kemudian nilai terendah sebesar 23.082 KVA dan untuk nilai rata-rata sebesar 27.783 KVA. Sehingga daya semu (S) total yang diserap motor untuk nilai tertinggi 36.166 KVA, kemudian nilai terendah 23.084 KVA dan untuk nilai rata-rata sebesar 27.673 KVA.

\subsection{Harmonisa Tegangan}

Hasil Pengukuran total harmonic distortion (THD) tegangan yang telah dilakukan mendapatkan data sebagai berikut. 


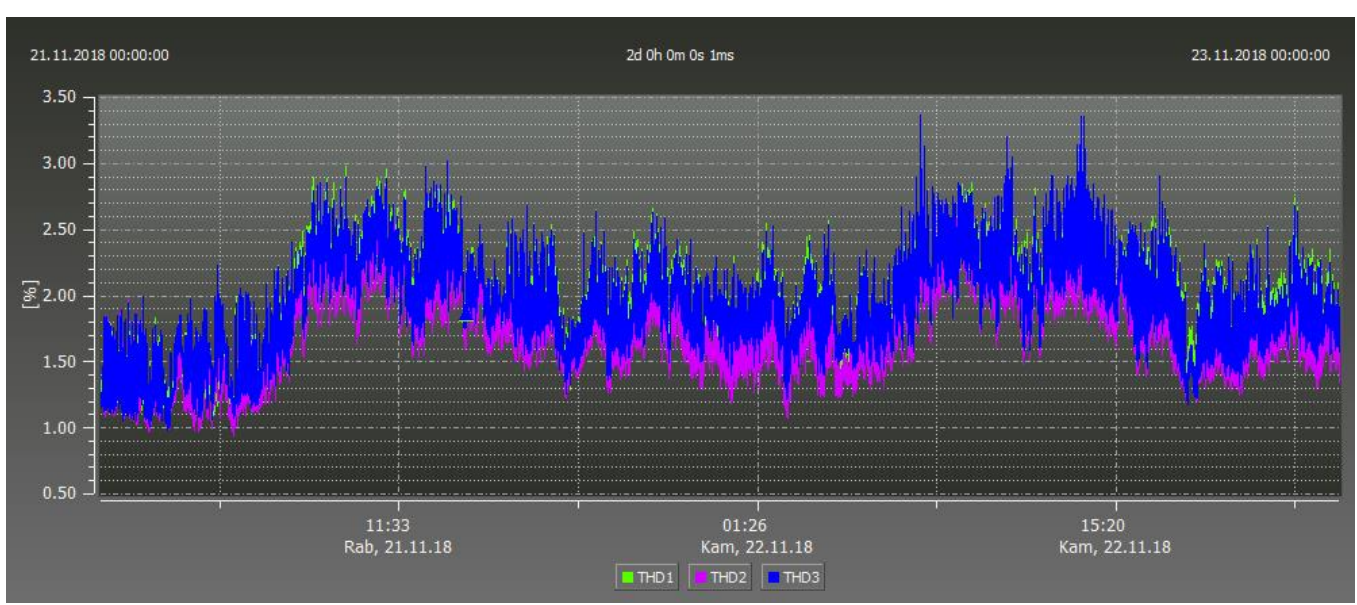

Gambar 11. Grafik THD Tegangan

Gambar 11 menjelaskan THD tegangan pada tiap fasa THD1(R), THD2(S), \& THD3(T) dimana dalam grafik tersebut dijelaskan bahwa nilai harmonisa pada fasa THD1 (R) untuk nilai tertinggi sebesar $3.178 \%$, kemudian nilai terendah sebesar $1.028 \%$ dan untuk nilai rata-rata sebesar $1.918 \%$. Lalu nilai harmonisa pada fasa THD2 (S) untuk nilai tertinggi sebesar $3.160 \%$, kemudian nilai terendah sebesar $0.943 \%$ dan untuk rata-rata sebesar $1.763 \%$. terakhir pada fasa THD3 (T) nilai tertinggi sebesar $3.367 \%$, kemudian nilai terendah sebesar $0.986 \%$ dan untuk nilai rata-rata sebesar $1.896 \%$.

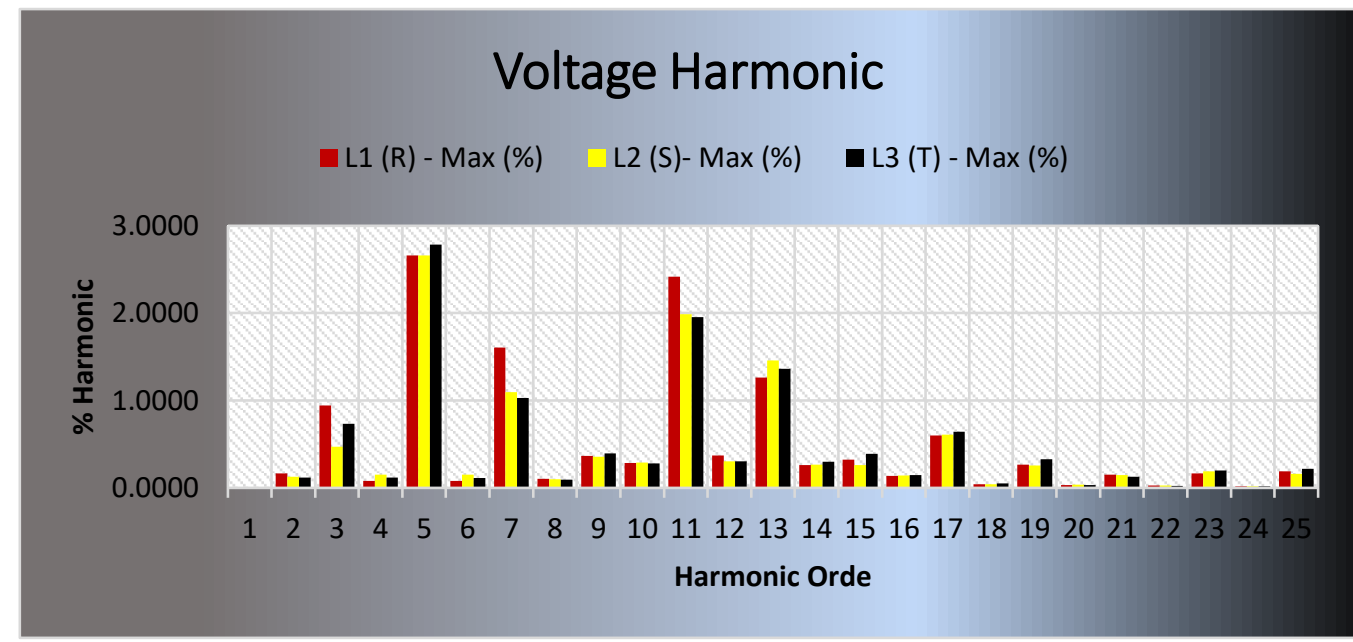

Gambar 12. Harmonik Plot Tegangan

Gambar 12 diatas menjelaskan bahwa harmonisa tegangan dengan nilai yang relatif tinggi terjadi pada orde ganjil yaitu pada orde ke 5 sebesar $2.7871 \%$ pada fasa L3 (T), orde ke 7 sebesar $1.6080 \%$ pada fasa $L 1(R)$, orde ke 11 sebesar $2.4160 \%$ pada fasa L1 $(R)$, orde ke 13 sebesar $1.4601 \%$ pada fasa L3 $(T)$, orde ke 17 sebesar $0.6439 \%$ kemudian untuk nilai terendah sebesar $0.1892 \%$ pada fasa $L 1(R)$ orde ke 25 .

\subsection{Harmonisa Arus}

Hasil Pengukuran total harmonic distortion (THD) arus yang telah dilakukan mendapatkan data sebagai berikut 


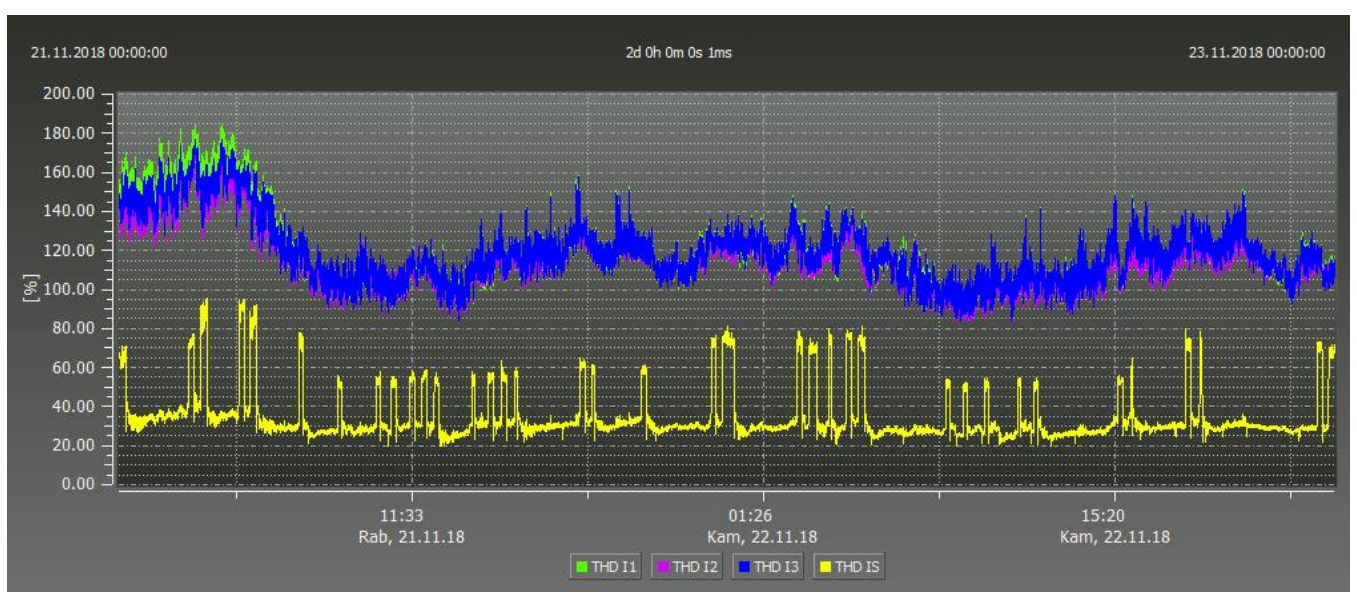

Gambar 13. Grafik Harmonisa Arus

Gambar 13 menjelaskan THD arus pada tiap fasa THD I1(R), THD I2(S), THD I3(T) $\%$ THD IS (N) dimana dalam grafik tersebut dijelaskan bahwa nilai harmonisa pada fasa THD I1 (R) untuk nilai tertinggi sebesar $184.230 \%$, kemudian nilai terendah sebesar $83.764 \%$ dan untuk nilai rata-rata sebesar $119.329 \%$. Lalu nilai harmonisa pada fasa THD 12 (S) untuk nilai tertinggi sebesar $177.037 \%$, kemudian nilai terendah sebesar $82.626 \%$ dan untuk rata-rata sebesar $116.927 \%$. pada fasa THD I3 (T) nilai tertinggi sebesar $177.050 \%$, kemudian nilai terendah sebesar $83.736 \%$ dan untuk nilai rata-rata sebesar $119.173 \%$. Terakhir pada fasa THD IS (N) nilai tertinggi sebesar $95.829 \%$, kemudian nilai terendah sebesar $19.533 \%$ dan untuk nilai rata-rata sebesar $35.159 \%$.

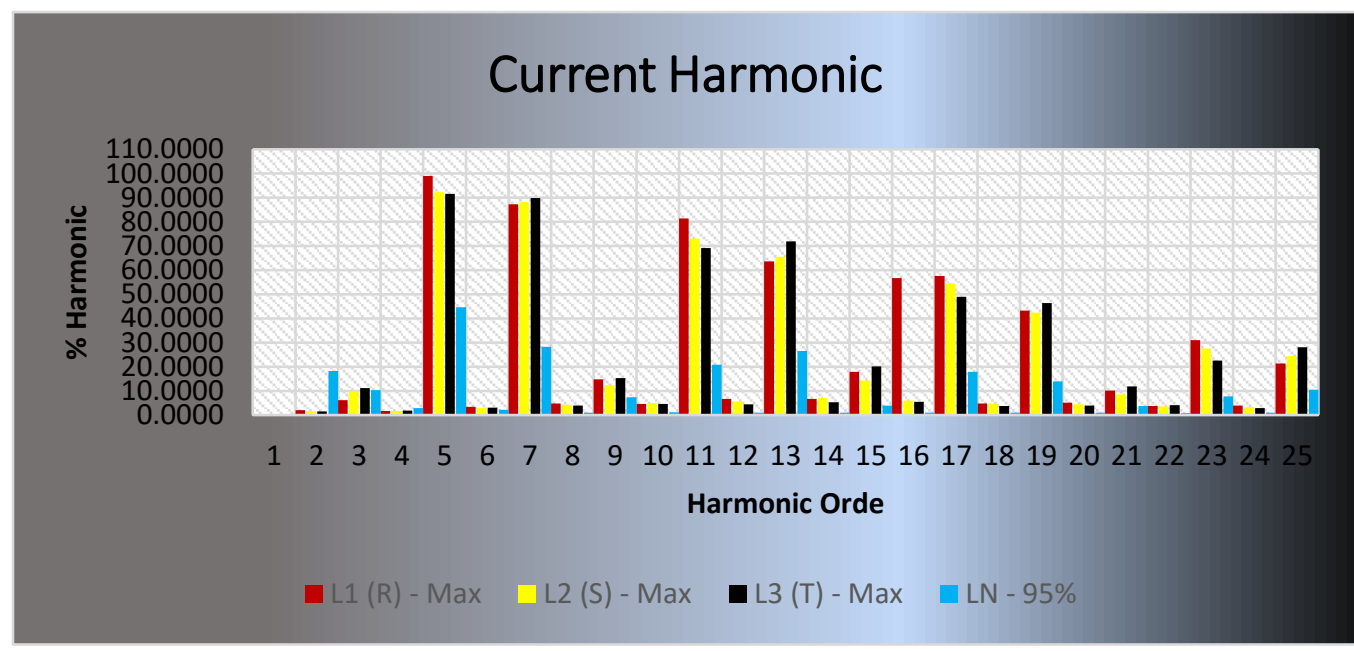

Gambar 14. Harmonik Plot Arus

Gambar 14 diatas menjelaskan bahwa harmonisa arus dengan nilai yang relatif tinggi terjadi pada orde ganjil yaitu pada orde ke 5 sebesar $98.960 \%$ pada fasa $L 1(R)$, orde ke 7 sebesar $89.850 \%$ pada fasa $L 3(T)$, orde ke 11 sebesar $81.390 \%$ pada fasa $L 1$ $(\mathrm{R})$, orde ke 13 sebesar $71.844 \%$ pada fasa L3 $(\mathrm{T})$, orde ke 15 sebesar $17.884 \%$ pada fasa $L 1(R)$. kemudian untuk nilai terendah pada orde ke 25 sebesar $28.024 \%$ pada fasa L3 (T). 


\subsection{Pemasangan DC Reaktor Inverter}

Optimasi perbaikan faktor salah satunya dengan cara pemasangan dc reaktor, dc reaktor adalah komponen yang memiliki induktansi dalam jumlah tertentu yang fungsinya untuk mengkoreksi faktor daya dan mereduksi harmonisa pada sistem.
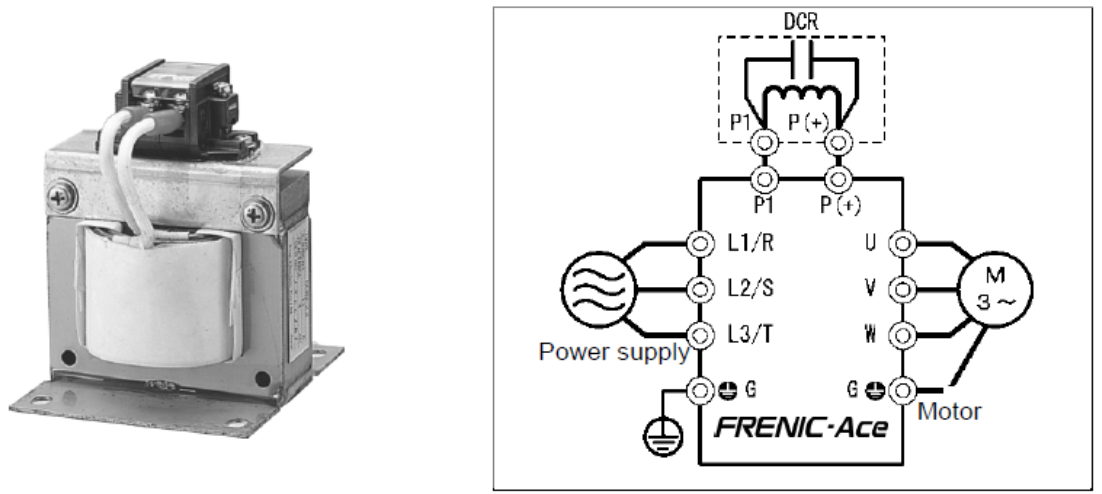

Gambar 15. DC Reaktor Fuji dan Wiring diagram

Spesifikasi dc reaktor yang terpasang adalah sabagai berikut:

Tabel 2. Spesifikasi DC Reaktor

\begin{tabular}{|c|l|c|}
\hline No & Spesification & Detail \\
\hline 1 & Power Supply Voltage & 3 Phase 400 V \\
\hline 2 & Nominal Applied motor $(\mathrm{kW})$ & 30 \\
\hline 3 & Nominal Applied motor $(\mathrm{HP})$ & 40 \\
\hline 4 & DC Reactor Type & DCR4-30B \\
\hline 5 & Rated Curent $(A)$ & 71 \\
\hline 6 & Inductance $(\mathrm{mH})$ & 0,86 \\
\hline 7 & Generated Loss $(\mathrm{W})$ & 35 \\
\hline
\end{tabular}

Pemilihan DC reaktor dengan spesifikasi tersebut berdasarkan analisa kebutuhan spesifikasi motor yang digunakan. Untuk diketahui motor yang digunakan dengan spesifikasi berikut:

Tabel 3. Spesifikasi Motor Pendingin

\begin{tabular}{|c|l|c|}
\hline No & $\begin{array}{l}\text { Spesification Three Phase } \\
\text { induction Motor TITAN }\end{array}$ & Detail \\
\hline 1 & Type & Y2-200L-4 \\
\hline 2 & Pole & 4 \\
\hline 3 & Nominal Applied motor (kW) & 30 \\
\hline 4 & Curent design Factory & $57.6 \mathrm{~A}$ \\
\hline 5 & Nominal Applied motor (HP) & 40 \\
\hline 6 & Serial No & SM0914106 \\
\hline 7 & Frame Size & $200 \mathrm{~L}$ \\
\hline 8 & RPM & 1470 \\
\hline 9 & Frequency & $50 \mathrm{~Hz}$ \\
\hline
\end{tabular}




\begin{tabular}{|c|l|c|}
10 & $I P$ & 55 \\
\hline 11 & WT. & $240 \mathrm{Kg}$ \\
\hline
\end{tabular}

Dengan spesifikasi tersebut maka $D C$ reactor type $D C R 4-30 B$ dipilih sebagai pilihan terbaik dan akan dipasang pada inverter motor pendingin.

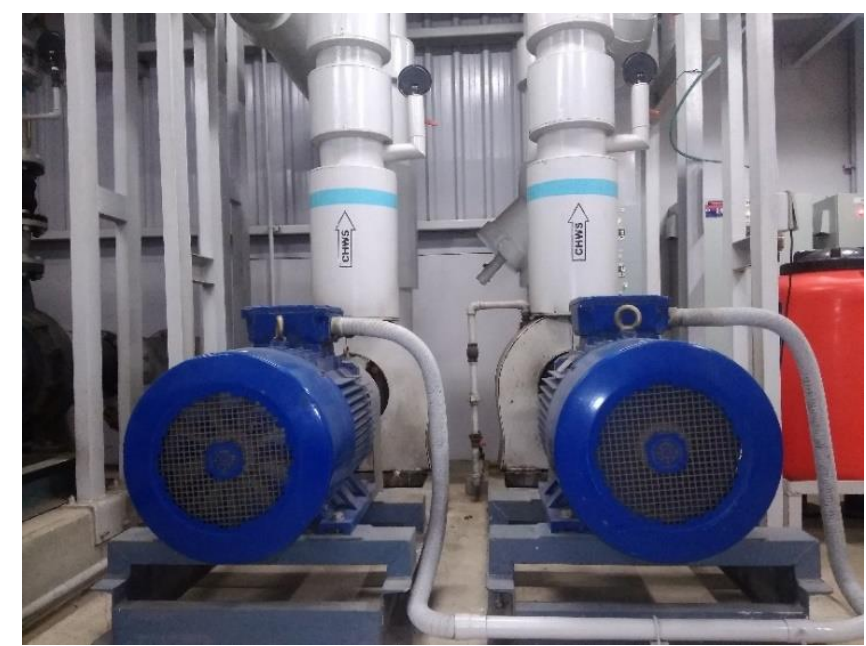

Gambar 16. Motor Pendingin Air Industri

Setelah dilakukan optimasi perbaikan faktor daya dengan pemasangan dc reaktor. kemudian diterjemahkan melalui grafik, maka langkah selanjutnya adalah mengukur ulang komponen besaran listrik yang dianalisa yaitu faktor daya, tegangan, arus, daya aktif, daya reaktif dan harmonisa menggunakan power analyser PQ BOX 100 dengan tujuan untuk mendapat data yang akurat terhadap komponen besaran listrik tersebut.

\subsection{Faktor Daya} berikut.

Hasil pengukuran faktor daya yang telah dilakukan mendapatkan data sebagai

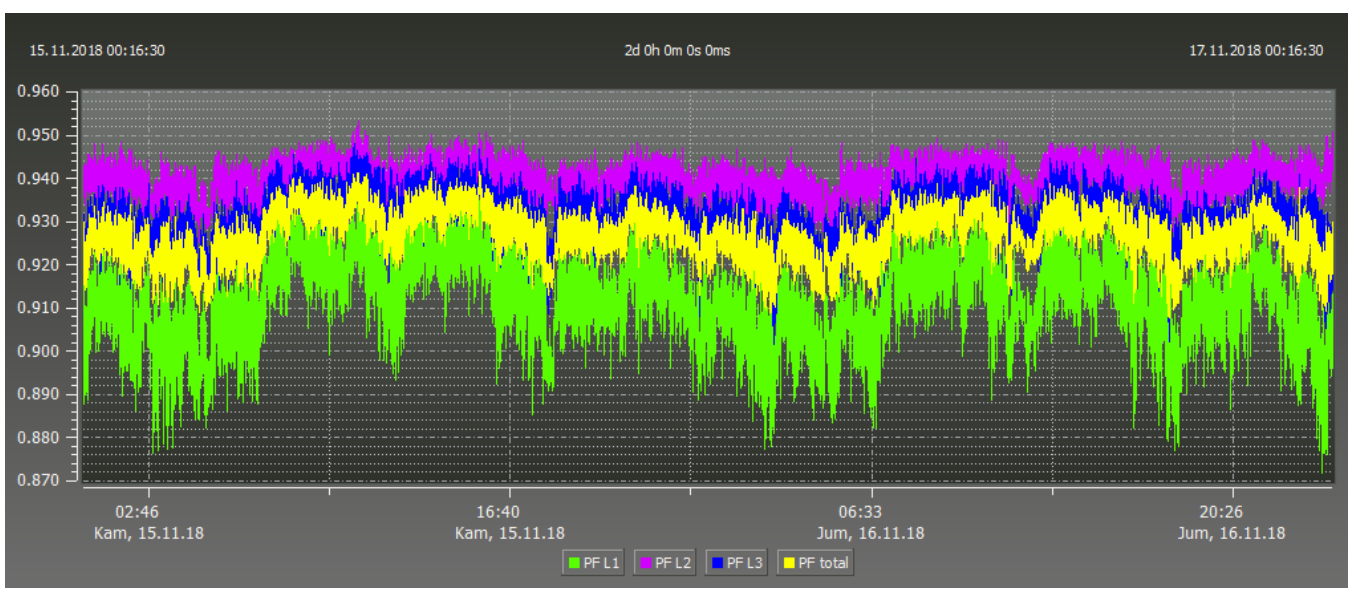

Gambar 17. Faktor Daya Sesudah Optimasi

Gambar 17 merupakan faktor daya total tiap fasa L1 (R), L2 (S), L3 (T). Dalam gambar tersebut dijelaskan bahwa nilai faktor daya tertinggi sebesar 0.942 , untuk nilai 
terendah sebesar 0.908 dan rata-rata sebesar 0.927 . kemudian bila komponen tersebut dipisah kan menjadi tiap fasa maka data yang didapat seperti berikut.

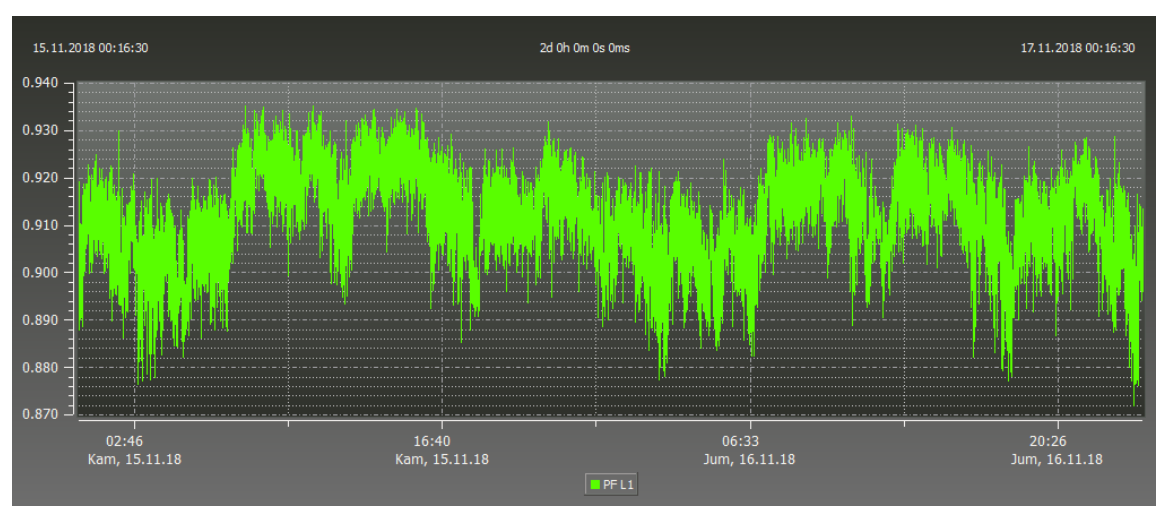

Gambar 18. Faktor Daya L1 (R) Sesudah

Pada gambar 18 merupakan grafik faktor daya fasa L1 $(R)$ dalam grafik tersebut menjelaskan bahwa nilai faktor daya tertinggi sebesar 0.935. untuk faktor daya terendah sebesar 0.872 dan rata-rata sebesar 0.912 . Kemudian untuk faktor daya fasa L2 (S) grafik yang didapat seperti gambar berikut.

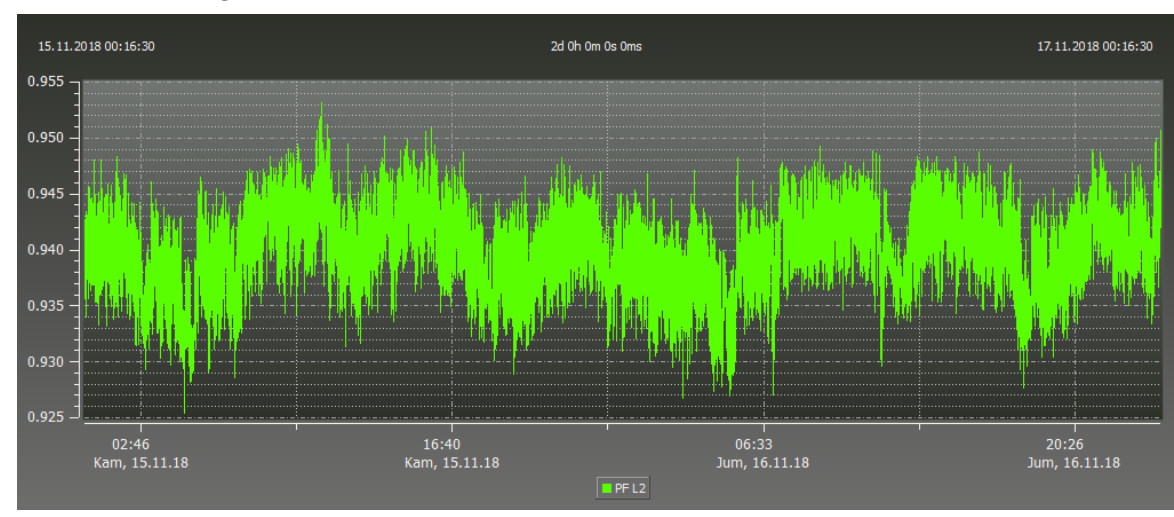

Gambar 19. Faktor Daya L2 (S) Sesudah

Pada gambar 19 merupakan grafik faktor daya fasa L2 (S) dalam grafik tersebut menjelaskan bahwa nilai faktor daya tertinggi sebesar 0.953. untuk faktor daya terendah sebesar 0.925 dan rata-rata sebesar 0.940 .

Kemudian untuk faktor daya fasa L3 (T) grafik yang didapat seperti gambar berikut.

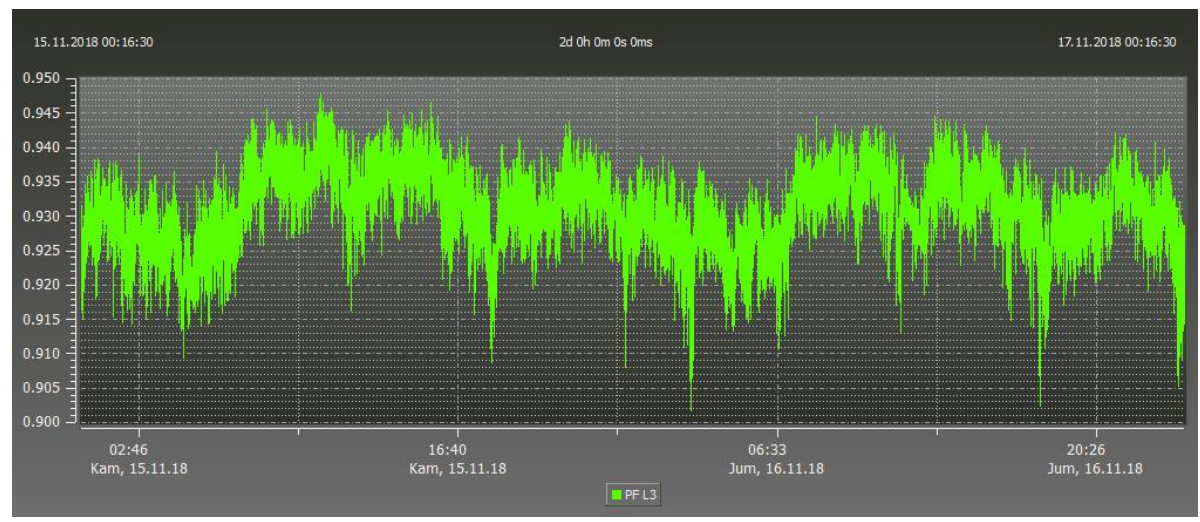

Gambar 20. Faktor Daya L3 (T) Sesudah 
Pada gambar 20 merupakan grafik faktor daya fasa L3 (T) dalam grafik tersebut menjelaskan bahwa nilai faktor daya tertinggi sebesar 0.948.untuk faktor daya terendah sebesar 0.902 dan rata-rata sebesar 0.931 .

\subsection{Tegangan}

Hasil pengukuran tegangan yang telah dilakukan mendapatkan data sebagai berikut.

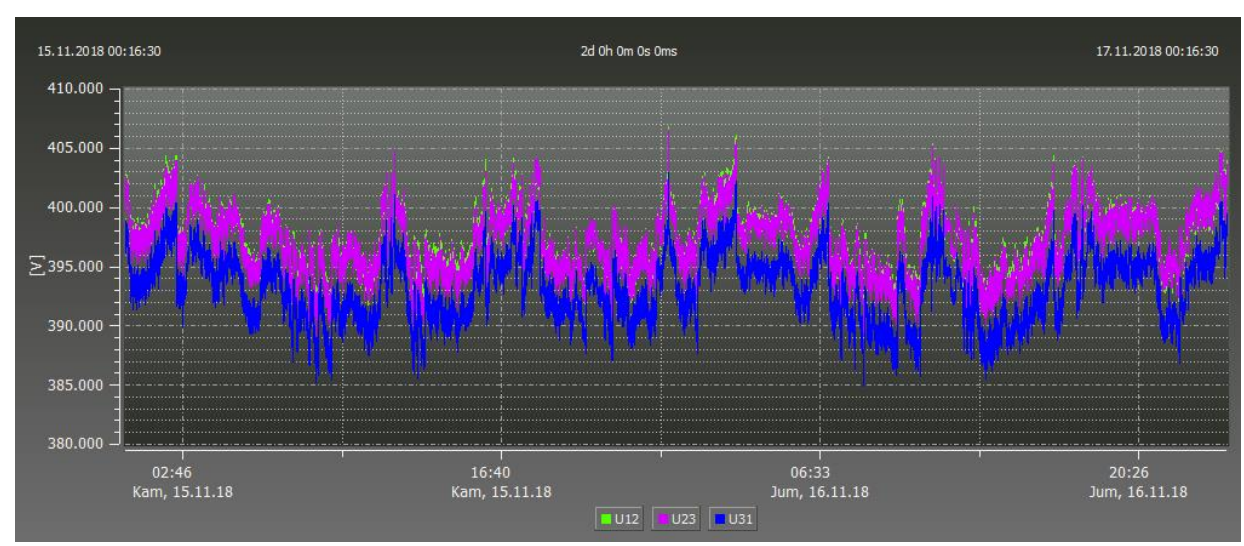

Gambar 21. Grafik Tegangan L1, L2, L3 (RST) Sesudah

Gambar 21 menjelaskan grafik tegangan pada tiap fasa L1(R), L2(S), \& L3(T) dimana dalam grafik tersebut dijelaskan bahwa nilai tegangan pada fasa $L 12$ (RS) untuk nilai tertinggi sebesar $406.789 \mathrm{~V}$, kemudian nilai terendah sebesar $389.625 \mathrm{~V}$ dan untuk rata-rata sebesar $397.311 \mathrm{~V}$. Lalu nilai tegangan pada fasa L23 (ST) untuk nilai tertinggi sebesar $406.514 \mathrm{~V}$, kemudian nilai terendah sebesar $389.254 \mathrm{~V}$ dan untuk rata-rata sebesar $397.137 \mathrm{~V}$. terakhir pada fasa L31 (TR) nilai tertinggi sebesar $402.923 \mathrm{~V}$, kemudian nilai terendah sebesar $384.944 \mathrm{~V}$ dan untuk nilai rata-rata.

\subsection{Arus}

Hasil pengukuran arus yang telah dilakukan mendapatkan data sebagai berikut.

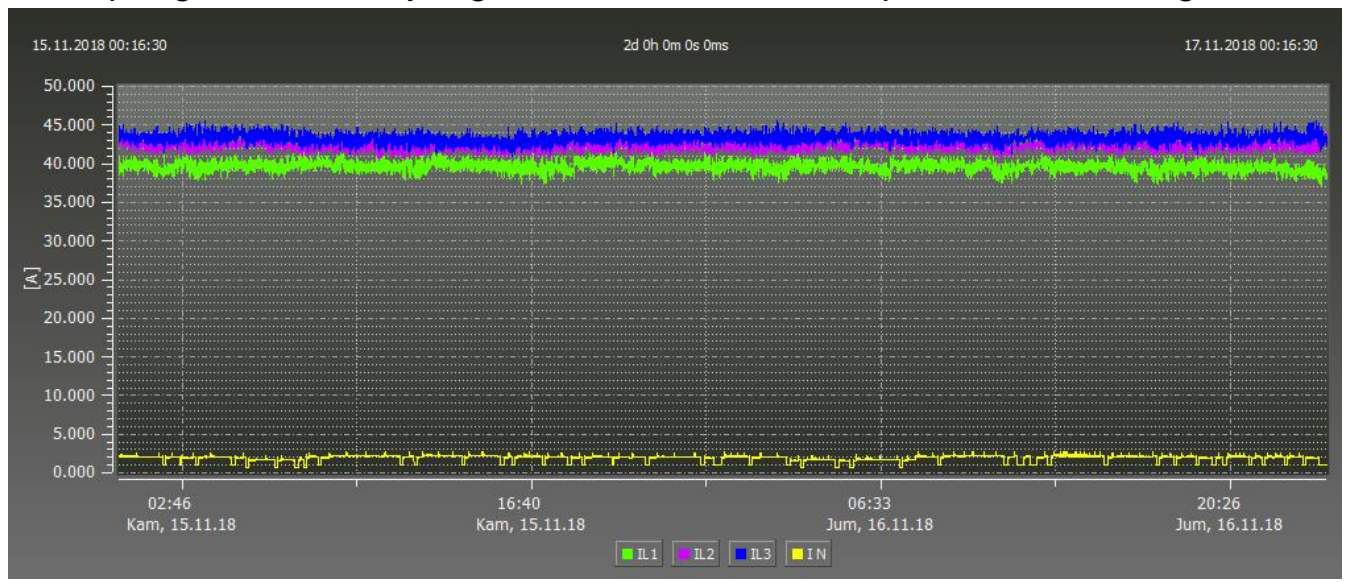

Gambar 22. Grafik Arus L1, L2, L3 (RST) Sesudah

Gambar 22 menjelaskan grafik arus pada tiap fasa IL1(R) , IL2(S), \& IL3(T) dimana dalam grafik tersebut dijelaskan bahwa nilai arus pada fasa IL1 $(R)$ untuk nilai tertinggi sebesar $41.771 \mathrm{~A}$, kemudian nilai terendah sebesar $37.128 \mathrm{~A}$ dan untuk nilai rata-rata 
sebesar 39.646 A. Lalu nilai arus pada fasa IL2 (S) untuk nilai tertinggi sebesar $44.442 \mathrm{~A}$, kemudian nilai terendah sebesar $40.490 \mathrm{~A}$ dan untuk rata-rata sebesar $42.637 \mathrm{~A}$. pada fasa IL3 (T) nilai tertinggi sebesar 45.569 A, kemudian nilai terendah sebesar $40.986 \mathrm{~A}$ dan untuk nilai rata-rata sebesar 43.261 A. terakhir pada fasa IN nilai tertinggi sebesar 2.744 A kemudian nilai terendah $0.679 \mathrm{~A}$ dan untuk nilai rata-rata $1.917 \mathrm{~A}$.

\subsection{Daya Aktif}

Hasil pengukuran daya aktif yang telah dilakukan mendapatkan data sebagai berikut.

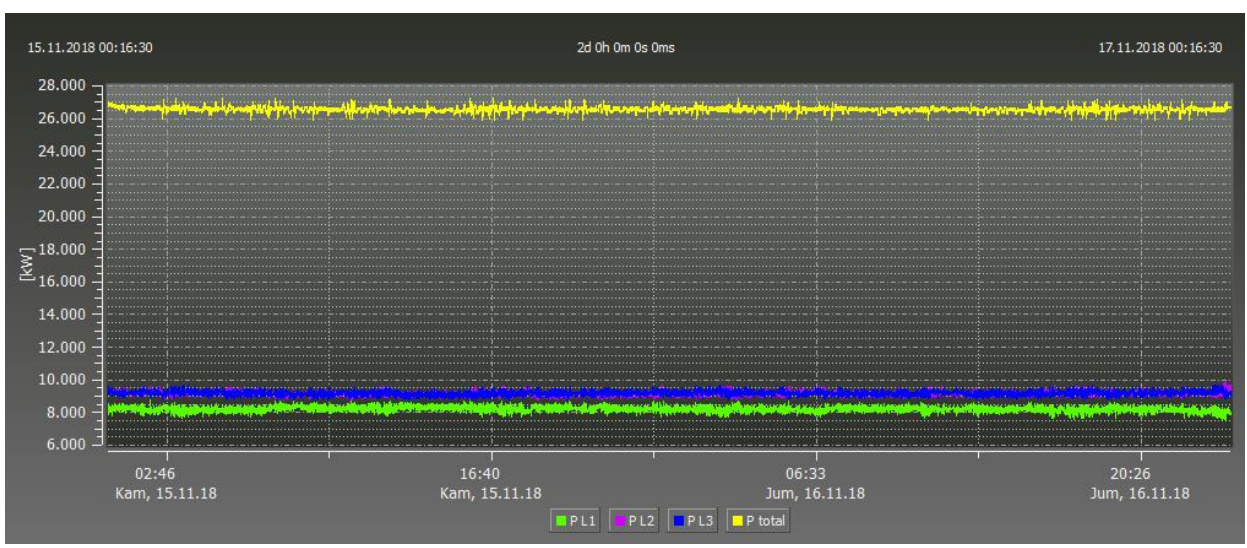

Gambar 23. Grafik Daya Aktif Sesudah

Gambar 23. menjelaskan grafik daya aktif pada tiap fasa PL1(R), PL2(S), \& PL3(T) dimana dalam grafik tersebut dijelaskan bahwa nilai daya aktif pada fasa PL1(R) untuk nilai tertinggi sebesar $8.787 \mathrm{KW}$, kemudian nilai terendah sebesar $7.490 \mathrm{KW}$ dan untuk nilai rata-rata sebesar $8.221 \mathrm{KW}$. Lalu nilai daya aktif pada fasa PL2(S) untuk nilai tertinggi sebesar $9.892 \mathrm{KW}$, kemudian nilai terendah sebesar $8.707 \mathrm{KW}$ dan untuk ratarata sebesar $9.162 \mathrm{KW}$. selanjutnya pada fasa PL3(T) nilai tertinggi sebesar $9.702 \mathrm{KW}$, kemudian nilai terendah sebesar $8.727 \mathrm{KW}$ dan untuk nilai rata-rata sebesar $9.182 \mathrm{KW}$. Sehingga daya aktif $(P)$ total yang diserap motor untuk nilai tertinggi $27.246 \mathrm{KW}$, kemudian nilai terendah $25.879 \mathrm{KW}$ dan untuk nilai rata-rata sebesar $26.565 \mathrm{KW}$.

\subsection{Daya Reaktif}

Hasil pengukuran daya reaktif yang telah dilakukan mendapatkan data sebagai berikut.

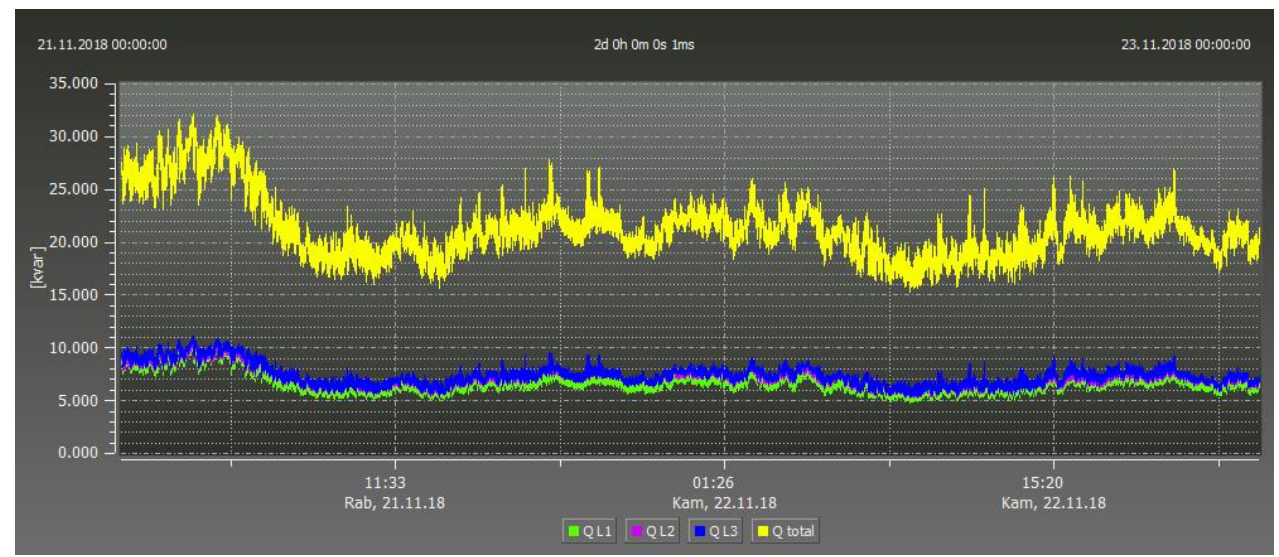

Gambar 24. Grafik Daya Reaktif Sesudah 
Gambar 24 menjelaskan grafik daya reaktif pada tiap fasa QL1(R), QL2(S), \& QL3(T) dimana dalam grafik tersebut dijelaskan bahwa nilai daya reaktif pada fasa QL1(R) untuk nilai tertinggi sebesar 4.299 KVar, kemudian nilai terendah sebesar 3.214 $\mathrm{KVar}$ dan untuk nilai rata-rata sebesar $3.696 \mathrm{KVar}$. Lalu nilai daya reaktif pada fasa QL2(S) untuk nilai tertinggi sebesar $3.704 \mathrm{KVar}$, kemudian nilai terendah sebesar 2.936 KVar dan untuk rata-rata sebesar 3.331 KVar. Selanjutnya pada fasa QL3(T) nilai tertinggi sebesar $4.312 \mathrm{KVar}$, kemudian nilai terendah sebesar 3.117 KVar dan untuk nilai rata-rata sebesar 3.601 KVar. Sehingga daya reaktif (Q) total yang diserap motor untuk nilai tertinggi $12.238 \mathrm{KVar}$, kemudian nilai terendah $9.465 \mathrm{KVar}$ dan untuk nilai rata-rata sebesar 12.238 Kvar.

\subsection{Daya Semu}

Hasil Pengukuran daya semu yang telah dilakukan mendapatkan data sebagai berikut.

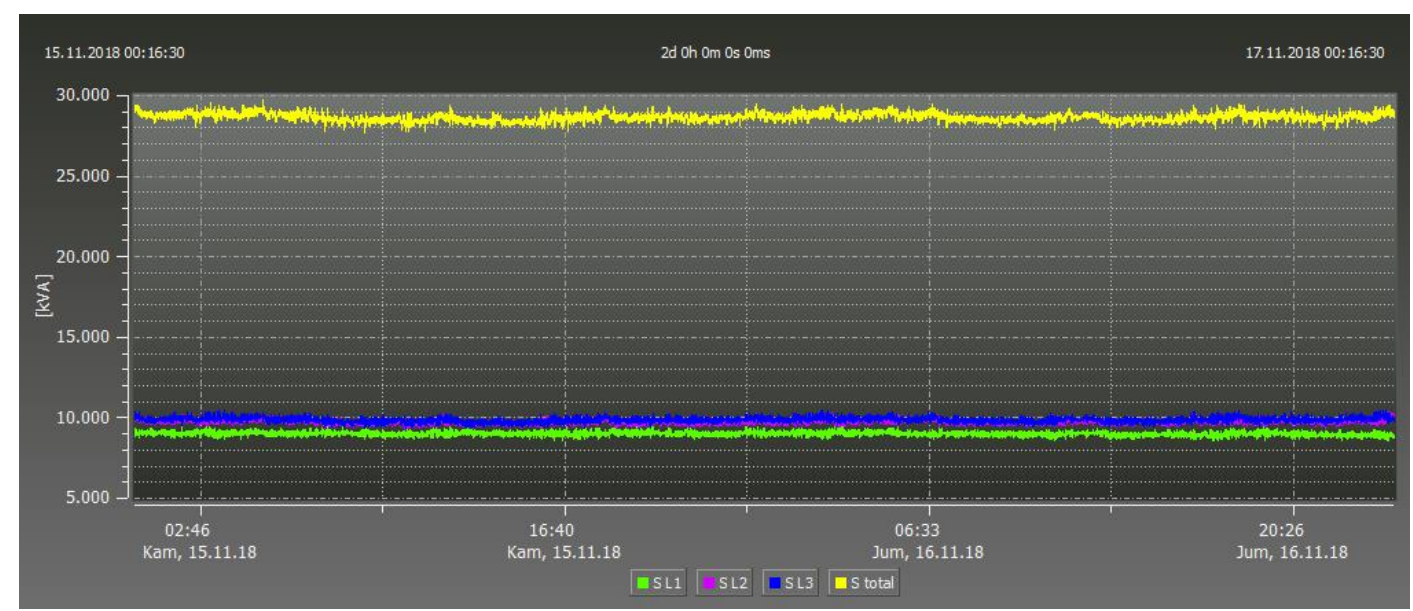

Gambar 25. Grafik Daya Semu Sesudah

Gambar 25. menjelaskan grafik daya semu pada tiap fasa SL1(R), SL2(S), \& SL3(T) dimana dalam grafik tersebut dijelaskan bahwa nilai daya semu pada fasa SL1(R) untuk nilai tertinggi sebesar 9.492 KVA, kemudian nilai terendah sebesar 8.549 KVA dan untuk nilai rata-rata sebesar 9.016 KVA. Lalu nilai daya semu pada fasa SL2(S) untuk nilai tertinggi sebesar $10.416 \mathrm{KVA}$, kemudian nilai terendah sebesar $9.750 \mathrm{KVA}$ dan untuk rata-rata sebesar 9.275 KVA. Selanjutnya pada fasa SL3(T) nilai tertinggi sebesar 10.503 KVA, kemudian nilai terendah sebesar 9.383 KVA dan untuk nilai rata-rata sebesar 9.864 KVA. Sehingga daya semu (S) total yang diserap motor untuk nilai tertinggi 29.758 KVA, kemudian nilai terendah 27.724 KVA dan untuk nilai rata-rata sebesar $28.663 \mathrm{KVA}$. 


\subsection{Harmonisa Tegangan}

Hasil Pengukuran total harmonic distortion (THD) tegangan yang telah dilakukan mendapatkan data sebagai berikut.

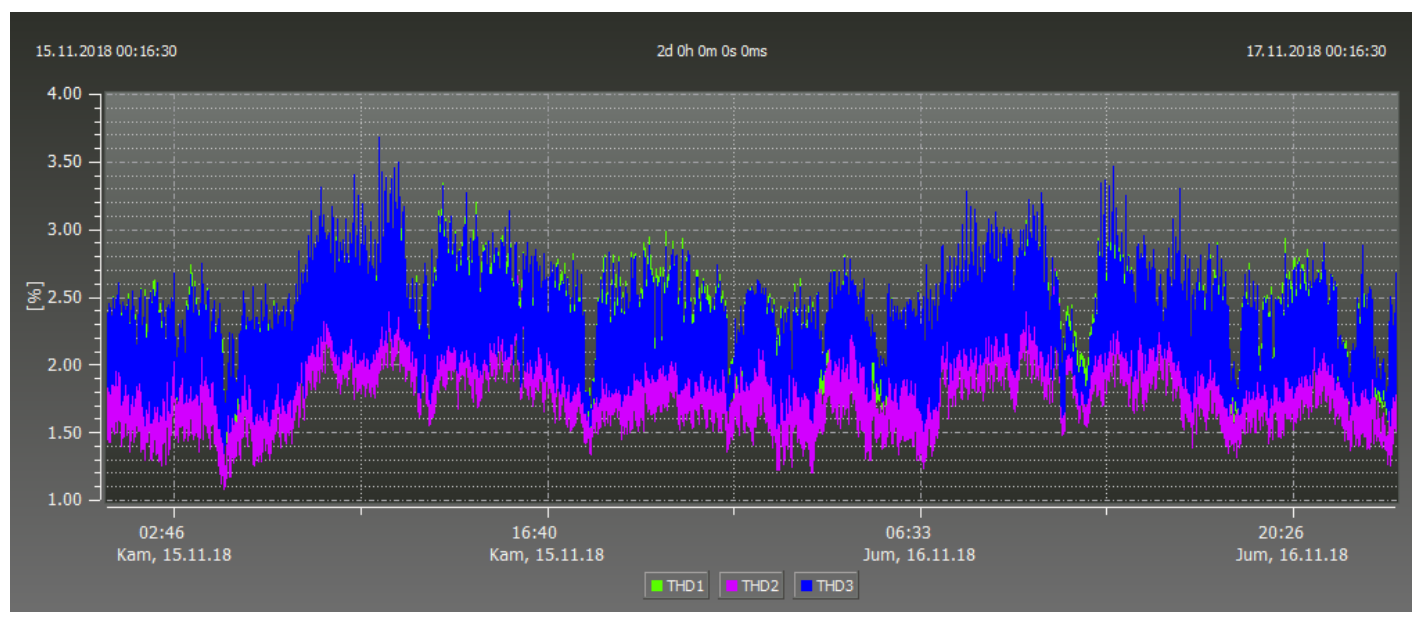

Gambar 26. Grafik THD Tegangan

Gambar 26. menjelaskan THD tegangan pada tiap fasa THD1(R), THD2(S), \& THD3(T) dimana dalam grafik tersebut dijelaskan bahwa nilai harmonisa pada fasa THD1 (R) untuk nilai tertinggi sebesar $3.589 \%$, kemudian nilai terendah sebesar $1.410 \%$ dan untuk nilai rata-rata sebesar $2.121 \%$. Lalu nilai harmonisa pada fasa THD2 (S) untuk nilai tertinggi sebesar $3.384 \%$, kemudian nilai terendah sebesar $1.904 \%$ dan untuk ratarata sebesar $1.083 \%$. terakhir pada fasa THD3 (T) nilai tertinggi sebesar $3.677 \%$, kemudian nilai terendah sebesar $1.346 \%$ dan nilai rata-rata sebesar $2.142 \%$.

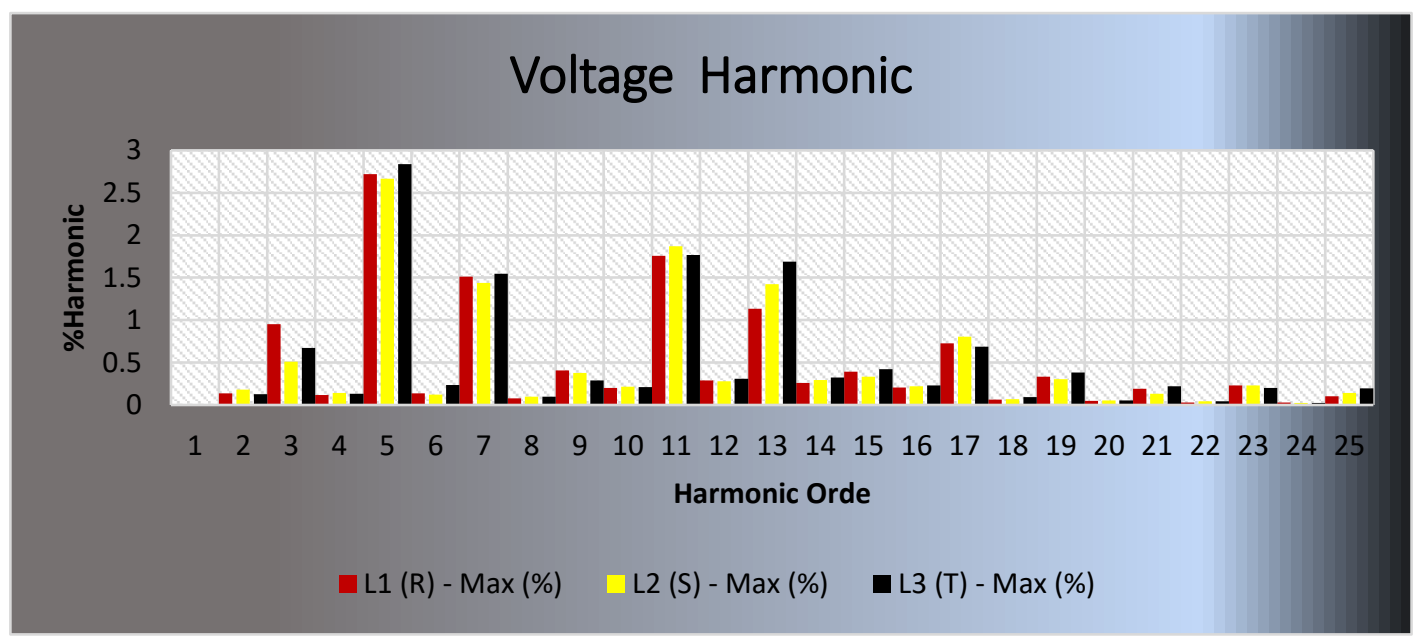

Gambar 27. Harmonisa Tegangan Setelah Optimasi

Gambar 27. diatas menjelaskan bahwa harmonisa tegangan dengan nilai yang relatif tinggi terjadi pada orde ganjil yaitu pada orde ke 5 sebesar $2.838 \%$ pada fasa L3 (T), ), orde ke 7 sebesar $1.547 \%$ pada fasa L3 (T), orde ke 11 sebesar $1.868 \%$ pada fasa $\mathrm{L} 2(\mathrm{~S})$, orde ke 13 sebesar $1.691 \%$ pada fasa $\mathrm{L} 3(\mathrm{~T})$, kemudian untuk nilai terendah sebesar $0.103 \%$ pada fasa L1 (R) orde ke 25 . 


\subsection{Harmonisa Arus}

Hasil Pengukuran total harmonic distortion (THD) arus yang telah dilakukan mendapatkan data sebagai berikut.

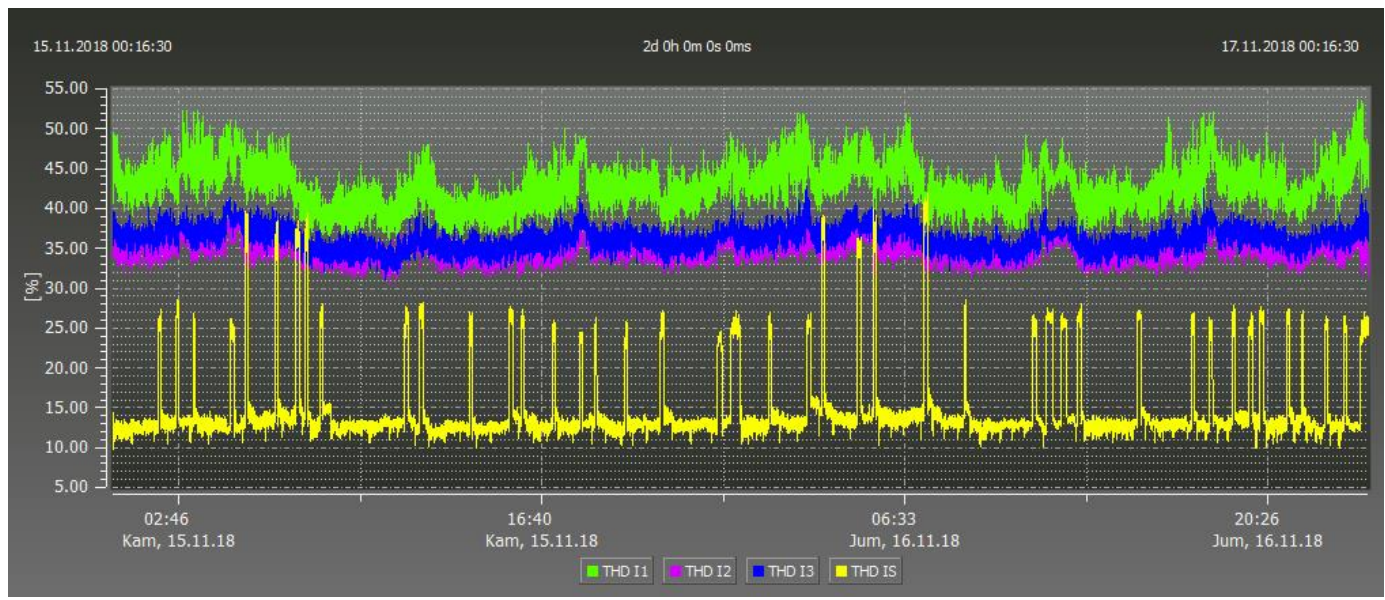

Gambar 28. Grafik Harmonisa Arus Sesudah

Gambar 28 menjelaskan THD arus pada tiap fasa THD I1(R), THD I2(S), THD I3(T) $\%$ THD IS (N) dimana dalam grafik tersebut dijelaskan bahwa nilai harmonisa pada fasa THD I1 (R) untuk nilai tertinggi sebesar $53.553 \%$, kemudian nilai terendah sebesar $35.788 \%$ dan untuk nilai rata-rata sebesar $42.952 \%$. Lalu nilai harmonisa pada fasa THD 12 (S) untuk nilai tertinggi sebesar $39.714 \%$, kemudian nilai terendah sebesar $30.456 \%$ dan untuk rata-rata sebesar $35.073 \%$. pada fasa THD I3 (T) nilai tertinggi sebesar $42.650 \%$, kemudian nilai terendah sebesar $31.043 \%$ dan untuk nilai rata-rata sebesar $36.189 \%$. Terakhir pada fasa THD IS (N) nilai tertinggi sebesar $41.816 \%$, kemudian nilai terendah sebesar $9.702 \%$ dan untuk nilai rata-rata sebesar $14.685 \%$.

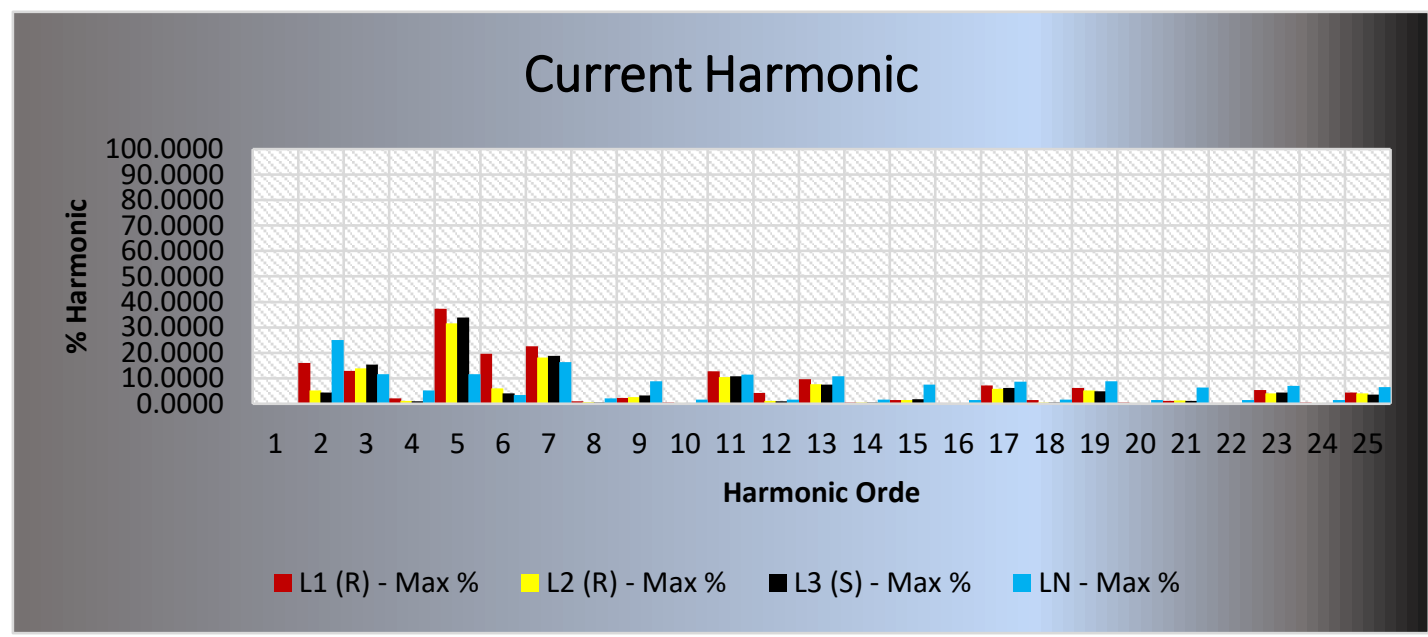

Gambar 29. Harmonisa Arus setelah perbaikan

Gambar 29. diatas menjelaskan bahwa harmonisa arus dengan nilai yang relatif tinggi terjadi pada orde ganjil yaitu pada orde ke 5 sebesar $37.328 \%$ pada fasa $L 1(R)$, orde ke 7 sebesar $22.550 \%$ pada fasa L1 (R), orde ke 11 sebesar $12.807 \%$ pada fasa L1 (R), orde ke 13 sebesar $10.857 \%$ pada fasa L3 $(T)$. kemudian untuk nilai terendah pada orde ke 25 sebesar $3.568 \%$ pada fasa L3 $(\mathrm{T})$. 


\subsection{Pembahasan}

Berdasarkan data yang sudah didapat mengenai optimasi perbaikan faktor daya dengan pemasangan DC reaktor akan mereduksi harmonisa didapat hasil penelitian bahwa optimasi perbaikan tersebut berhasil menaikan faktor daya yang sebelumnya nilai tertinggi sebesar 0.748 , untuk nilai terendah sebesar 0.478 dan rata-rata sebesar 0.634 , menjadi nilai tertinggi sebesar 0.942 , untuk nilai terendah sebesar 0.908 dan rata-rata sebesar 0.927 atau bila di persentasekan dari nilai terendah sebelum optimasi dan nilai tertinggi sesudah optimasi maka terjadi perbaikan sebesar $97 \%$.

Perbaikan tersebut terjadi karena dengan penambahan nilai impedansi dalam pemasangan DC reaktor maka secara otomatis menaikan power factor itu sendiri. Hal ini bisa dibuktikan dengan persamaan $\cos \phi=\frac{R}{Z}$ dengan naiknya nilai Z yang mendekati nilai $\mathrm{R}$ maka faktor daya akan bisa mendekati 1 . Seperti diketahui impedansi terdiri dari 2 komponen pembentuk yaitu $X L=2 \pi f L \quad \& \quad X C=\frac{1}{2 \pi f C}$ jika mampu memperbesar nilai induktansi dan memperkecil kapasitansi maka reaktansi total $(X)$ akan bertambah dan pada akhirnya nilai tersebut menjadi kunci dalam optimasi perbaikan faktor daya dengan pemasangan DC reaktor.

Hasil lain yang didapat adalah dengan membaiknya nilai faktor daya maka secara langsung nilai THD (total harmonic distortion) arus mengalami perbaikan secara signifikan dimana nilai harmonisa yang sebelum optimasi sebesar $184.230 \%$ pada fasa $L 1(R)$ turun menjadi $53.553 \%$ di fasa yang sama. Kemudian data lain yang didapatkan antara hubungan reaktansi kapasitif dengan harmonisa bila didetailkan dengan persamaan $X_{C}=$ $\frac{1}{2 \pi f C}$ dengan penjelasan $\mathrm{f}=$ frekuensi, $\mathrm{C}=$ kapasitor, maka semakin besar frekuensi harmonik maka nilai reaktansi kapasitif tersebut semakin besar hal ini bila dimasukan kedalam hukum ohm dimana $I=\frac{V}{R}$ hasilnya yaitu nilai resistansi semakin besar sehingga membutuhkan arus lebih banyak untuk menghasilkan daya yang sama. Hal ini diperkuat dengan nilai arus yang diserap oleh inverter motor tertinggi sebesar 55.453 A turun menjadi 45.569 A atau ada perbaikan sebesar 21,70\%. Dengan kata lain perbaikan faktor daya yg dilakukan pada inverter menggunakan DC Reaktor secara langsung mempengaruhi nilai harmonisa yang dihasilkan oleh inverter tersebut sehingga nilai harmonisa menjadi lebih baik bila dibandingkan dengan sebelum optimasi.

\section{KESIMPULAN DAN SARAN}

\subsection{Kesimpulan}

Berdasarkan data yang sudah didapat mengenai optimasi perbaikan faktor daya dengan pemasangan dc reaktor akan mereduksi harmonisa di inverter motor pendingin air industri maka didapat kesimpulan sebagai berikut :

1. Dengan pemasangan DC reaktor maka akan menambah nilai impedansi pada inverter motor dengan persamaan $\cos \phi=\frac{R}{Z}$ dengan naiknya nilai $Z$ yang mendekati nilai $\mathrm{R}$ maka faktor daya akan bisa mendekati 1 .

2. Dengan naiknya nilai impedansi yang ditambahkan oleh DC reaktor maka nilai THD harmonisa arus akan menurun akibat penambahan nilai impedansi inverter.

3. Perbaikan optimum yang dicapai untuk faktor daya adalah sebesar 0.942 sedangkan untuk harmonisa sebesar $55.553 \%$ pada fasa L1. 


\subsection{Saran}

Dari penelitian optimasi perbaikan faktor daya dengan pemasangan dc reaktor akan mereduksi harmonisa di inverter motor pendingin air industri penulis memberi saran untuk melakukan monitoring rutin terhadap kondisi faktor daya setelah pemasangan DC reaktor dengan tujuan untuk melihat hasil dari optimasi tersebut.

\section{UCAPAN TERIMAKASIH}

Penulis mengucapkan terima kasih kepada Sekolah Tinggi Teknik PLN yang telah memberi dukungan yang membantu pelaksanaan penelitian dan atau penulisan artikel.

\section{DAFTAR PUSTAKA}

[1] HARDIRANTO, W. N. (2017). ANALISA OPTIMASI PERBAIKAN FAKTOR DAYA DAN DROP. Lampung: UNIVERSITAS LAMPUNG.

[2] Indhira Kusuma Wardhani, H. S. (2012). Analisis Pemasangan Detuned Reactor dan Perancangan Filter Harmonisa Pada Sistem Kelistrikan Pabrik Kaca. JURNAL TEKNIK POMITS, 1-6.

[3] Ir. Mohammad Amir, M. A. (2017). STUDI ANALISIS PENGARUH HARMONISA AKIBAT PENGGUNAAN. Sinusoida, XIX No. 2, 20-29.

[4] KURNIAWAN, I. (2012). ANALISIS PENGARUH HARMONISA TERHADAP PENYIMPANGAN PENGUKURAN ENERGI LISTRIK PADA KWH METER ANALOG DAN DIGITAL. Depok: UNIVERSITAS INDONESIA.

[5] Rahardjo, \& Yunus, Y. (2010). PERBAIKAN FAKTOR DAYA MOTOR INDUKSI 3 FASE. SEMINAR NASIONAL VI SDM Nuklir (hal. 451-458). Jogjakarta: STT Batan.

[6] Rosa La, F. C. (2006). HARMONICS AND POWER SYSTEMS. New York: CRC Press.

[7] Sylvia Handriyani, A. S. (2012). ANALISA PERBAIKAN FAKTOR DAYA UNTUK PENGHEMATAN BIAYA LISTRIK DI KUD TANI MULYO LAMONGAN. Surabaya: Jurusan Teknik Elektro FTI - ITS.

[8] Syracuse, C. C. (2005). OPERATION AND APPLICATION OF VARIABLE FREQUENCY DRIVE (VFD) TECHNOLOGY. New York: Syracuse, Carrier Corporation.

[9] Thomas M. Blooming, P. D. (2005). APPLICATION OF IEEE STD 519-1992 HARMONIC LIMITS. North Carolina, Pennsylvania: Eaton Electrical. 